\title{
Dolomite and Siliciclastic Dikes and Sills in Marginal-Marine Cretaceous Coals of Central Utah
}

\section{U.S. GEOLOGICAL SURVEY BULLETIN 2087-A}




\section{AVAILABILITY OF BOOKS AND MAPS OF THE U.S. GEOLOGICAL SURVEY}

Instructions on ordering publications of the U.S. Geological Survey, along with prices of the last offerings, are given in the current-year issues of the monthly catalog "New Publications of the U.S. Geological Survey." Prices of available U.S. Geological Survey publications released prior to the current year are listed in the most recent annual "Price and Availability List." Publications that may be listed in various U.S. Geological Survey catalogs (see back inside cover) but not listed in the most recent annual "Price and Availability List" may no longer be available.

Reports released through the NTIS may be obtained by writing to the National Technical Information Service, U.S. Department of Commerce, Springfield, VA 22161; please include NTIS report number with inquiry.

Order U.S. Geological Survey publications by mail or over the counter from the offices listed below.

\section{BY MAIL}

\section{Books}

Professional Papers, Bulletins, Water-Supply Papers, Techniques of Water-Resources Investigations, Circulars, publications of general interest (such as leaflets, pamphlets, booklets), single copies of Earthquakes \& Volcanoes, Preliminary Determination of Epicenters, and some miscellaneous reports, including some of the foregoing series that have gone out of print at the Superintendent of Documents, are obtainable by mail from

\section{U.S. Geological Survey, Map Distribution Box 25286, MS 306, Federal Center Denver, CO 80225}

Subscriptions to periodicals (Earthquakes \& Volcanoes and Preliminary Determination of Epicenters) can be obtained ONLY from the

\section{Superintendent of Documents Government Printing Office Washington, DC 20402}

(Check or money order must be payable to Superintendent of Documents.)

\section{Maps}

For maps, address mail orders to

\section{U. S. Geological Survey, Map Distribution Box 25286, Bldg. 810, Federal Center Denver, CO 80225}

Residents of Alaska may order maps from

U.S. Geological Survey, Earth Science Information Center 101 Twelfth Ave., Box 12

Fairbanks, AK 99701

\section{OVER THE COUNTER}

\section{Books and Maps}

Books and maps of the U.S. Geological Survey are available over the counter at the following U.S. Geological Survey offices, all of which are authorized agents of the Superintendent of Documents.

- ANCHORAGE, Alaska-Rm. 101, 4230 University Dr.

- LAKEWOOD, Colorado-Federal Center, Bldg. 810

- MENLO PARK, California-Bldg. 3, Rm. 3128, 345 Middlefield Rd.

- RESTON, Virginia-USGS National Center, Rm. 1C402, 12201 Sunrise Valley Dr.

- SALT LAKE CITY, Utah-Federal Bldg., Rm. 8105, 125 South State St.

- SPOKANE, Washington-U.S. Post Office Bldg., Rm. 135, West 904 Riverside Ave.

- WASHINGTON, D.C.-Main Interior Bldg., Rm. 2650, 18 th and C Sts., NW.

\section{Maps Only}

Maps may be purchased over the counter at the following U.S. Geological Survey offices:

- FAIRBANKS, Alaska-New Federal Bldg, 101 Twelfth Ave.

- ROLLA, Missouri-1400 Independence Rd.

- STENNIS SPACE CENTER, Mississippi-Bldg. 3101 


\title{
Dolomite and Siliciclastic Dikes and Sills in Marginal-Marine Cretaceous Coals of Central Utah
}

\author{
By John K. Hardie
}

CLASTIC DIKES IN CRETACEOUS COALS IN UTAH AND COLORADO

U.S. GEOLOGICAL SURVEY BULLETIN 2087-A

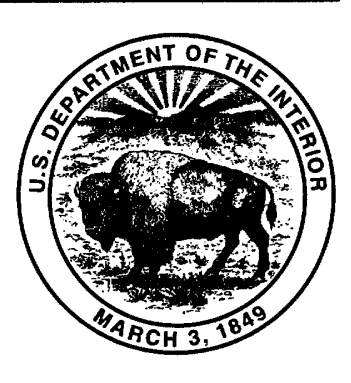

UNITED STATES GOVERNMENT PRINTING OFFICE, WASHINGTON : 1994 


\title{
U.S. DEPARTMENT OF THE INTERIOR BRUCE BABBITT, Secretary
}

\author{
U.S. GEOLOGICAL SURVEY \\ Gordon P. Eaton, Director
}

\author{
Published in the Central Region, Denver, Colorado \\ Manuscript approved for publication February 9, 1994 \\ Edited by Judith Stoeser \\ Graphics by John Hardie and Mari L. Kauffmann \\ Photocomposition by Mari L. Kauffmann
}

\section{For Sale by U.S. Geological Survey, Map Distribution \\ Box 25286, MS 306, Federal Center \\ Denver, CO 80225}

\begin{abstract}
Any use of trade, product, or firm names in this publication is for descriptive purposes only and does not imply endorsement by the U.S. Government
\end{abstract}

\section{Library of Congress Cataloging-in-Publication Data}

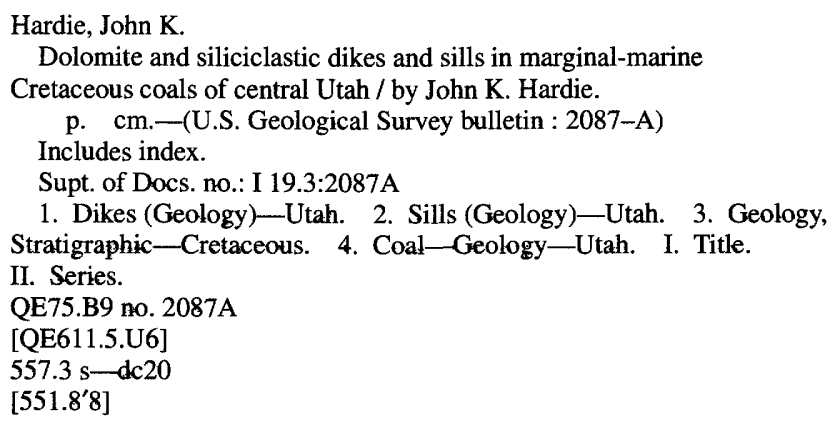




\section{CONTENTS}

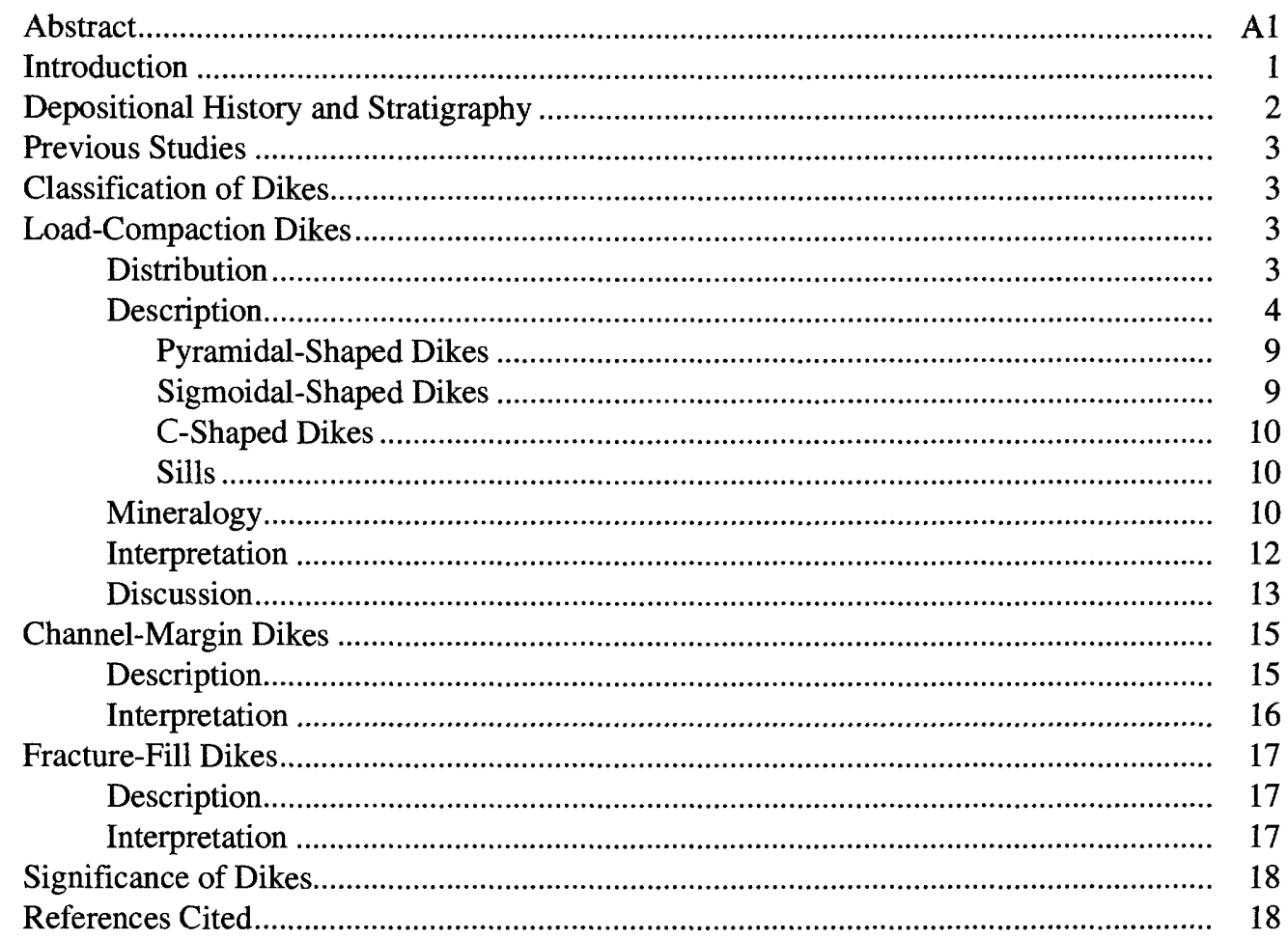

\section{FIGURES}

1. Index map showing location of study area in central Utah.

2. Schematic section showing emplacement of clastic dikes and sedimentary architecture......

3. Drawing showing distribution and orientation of load-compaction dikes and dike swarms in Trail Mountain mine

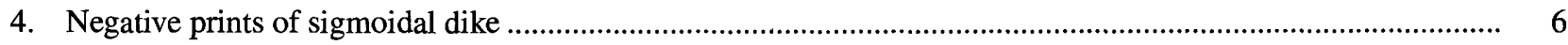

5. Photograph and schematic drawing showing sandstone floor rock cut and heaved by low-angle dike................. 7

6-10. Photographs showing:

6. Pyramidal-shaped dikes with different forms of secondary injection features attached to their termini ..... 8

7. Sigmoidal-shaped dike with sill attached to outside radius of sharp fold ............................................... 10

8. C-shaped dike in Hiawatha coal seam ................................................................................................... 11

9. Multiple clastic sills near base of coal seam....................................................................................... 11

10. Core containing small-scale dikes at top of marl lens below base of Hiawatha coal seam in Star Point Sandstone

11. Diagram showing trends of structural elements and related features in vicinity of Trail Mountain mine ............ 15

12. Photograph showing channel-margin dike attached to sandstone channel body in roof of coal seam ................. 16

13, 14. Sketches showing:

13. Large-scale channel-margin dike

14. Typical fracture-fill dike 


\title{
Dolomite and Siliciclastic Dikes and Sills in Marginal-Marine Cretaceous Coals of Central Utah
}

\author{
By John K. Hardie
}

\begin{abstract}
Clastic dikes intrude 13 of 15 commercial coal seams that span more than $250 \mathrm{~m}$ of section along the eastern flank of the Wasatch Plateau and the western Book Cliffs of central Utah. Dikes are grouped into three principle populations that reflect different modes of origin, distribution, and geometry. Channel-margin dikes are scattered siliciclastic bodies that rarely exceed $5 \mathrm{~cm}$ in thickness and seldom penetrate deeper than the upper meter of coal seams. Commonly, they are physically attached to channel-sandstone bodies that make up the roof of coal seams. These dikes form by infilling tears that develop in the peat along channel-body margins. Fracture-fill dikes are rare, high-angle siliciclastic bodies that rarely exceed $1 \mathrm{~m}$ in thickness and can cut entire coal seams. Their fault-bound margins, which cut entire coal seams, indicate that they formed by injection along fractures. Load-compaction dikes are by far the most abundant type of dike in the central part of the Wasatch Plateau. They can exceed $2 \mathrm{~m}$ in thickness and extend more than $450 \mathrm{~m}$ laterally. Load-compaction dikes are further divided into three subgroups: broad, pyramidal-shaped dikes that penetrate the lower part of coal seams; sigmoidal-shaped dikes, which are ribbonlike features that commonly cut entire coal seams at high angles; and rare C-shaped dikes, which are broad tabular injections that appear to cut entire coal seams. Load-compaction dikes are composed principally of dolomite and form from the sediment loading of water-saturated lenses of dolomitic marl interbedded in sandstone directly beneath peat. Evidence for this type of origin includes exposures showing sandstone floor rocks that have been heaved upward by dolomitic dikes that penetrate into the base of coal seams, the presence of dikes in swarms, and the petrology of the dike material, which is indistinguishable from that of the underlying marl lenses. Paleotopography, irregularities along the depositional surface of the peat, overpressuring of shoreface sandstone, and the physical characteristics of the peat may have had significant influence on dike formation. Clastic sills are common features that can exceed $10 \mathrm{~cm}$ in thickness and extend laterally more than $100 \mathrm{~m}$ from their origins at sigmoidal and pyramidal dikes. The sills are composed of microcrystalline dolomite that was squeezed from dikes
\end{abstract}

during peat compaction. Evidence for this type of origin includes the physical attachment of the sills to pyramidaland sigmoidal-shaped dikes, the abundant transposition structures in the sills, the fibrous character of the peat at the time of sill formation, and the similar petrology of sills and dikes.

Clastic dikes are common in coal seams that accumulated in marginal-marine settings and have caused a wide variety of serious mine problems. They were the principle factor in closing operations at the Cameo and Cameo No. 1 mines in western Colorado. Their presence in the Appalachian Basin has rendered some coal seams unminable.

\section{INTRODUCTION}

Clastic dikes (also called horsebacks, clay slips, rock faults, mud slips, rock spars, dumb faults, stone dikes, clay veins, clay seams, mud seams, nips, and rock-jumbles), as discussed herein, are tabular bodies that cut across coal bedding. They are composed of sedimentary material that was either deposited or injected from a source(s) outside the host coal seam. Clastic sills are tabular concordant bodies composed of sedimentary material that was extruded from a source(s) either inside (such as clastic dikes) or outside the host coal seam.

Dikes penetrate 13 of 15 minable coal seams that span more than $250 \mathrm{~m}$ of section along the Wasatch Plateau and western Book Cliffs of central Utah (fig. 1) (Hardie, 1991). They range from small features a few centimeters thick to massive intrusions more than $2 \mathrm{~m}$ thick that extend laterally as much as $480 \mathrm{~m}$. In mines where dikes are abundant and (or) their thicknesses exceed approximately $10 \mathrm{~cm}$ and cut deep into coal seams, they cause a wide variety of problems (Hardie and Fleck, 1991; Hardie, 1992; Shea-Albin, in press) including roof instability (Savage, 1910; Kerns, 1970; Dunrud, 1976; Hill and Bauer, 1984; Chase and Ulery, 1987), impaired coal production (Kerns, 1970; K. Fleck, Deer Creek mine, oral commun., 1990; L. Ruschke, Roadside mine, oral commun., 1993), roof vibration when cut (Ellenberger, 1979; Moebs and Stateham, 1986), 
increased ash (Doelling, 1979; Johnson, 1982), channeling of water and increased methane emissions (Shea-Albin, in press), methane ignition from sparks generated by coal-cutting equipment (L. Adair, oral commun., 1991), damage and increased wear of coal-cutting equipment (Ellenberger,1979; Moebs and Stateham, 1986), and increased disposal handling of mine waste (Ellenberger, 1979), and they are a hazard to mine personnel. Dikes that are either too thick or too hard to be cut by conventional mining equipment must be drilled and blasted repeatedly, sometimes delaying production for days (K. Fleck, oral commun., 1991). In both the eastern and western United States, clastic dikes have been a significant factor in mine closures (Boreck, 1986). In western Colorado, near the town of Grand Junction, dikes were a principal factor in closing operations at the Cameo (Dunrud, 1976) and Cameo No. 1 mines (L. Rushke, Roadside mine, oral commun., 1993). At the turn of the century, Gresley $(1897$, p. 39) wrote that the presence of dikes in the Appalachian Basin has rendered some coal seams worthless. He went on to say that "portions of the Pittsburgh coal seam in West Virginia have been found so thickly intersected thereby that mining operations had to be abandoned in such areas."

This investigation was conducted to determine the nature, distribution, geometry, and predictability of clastic

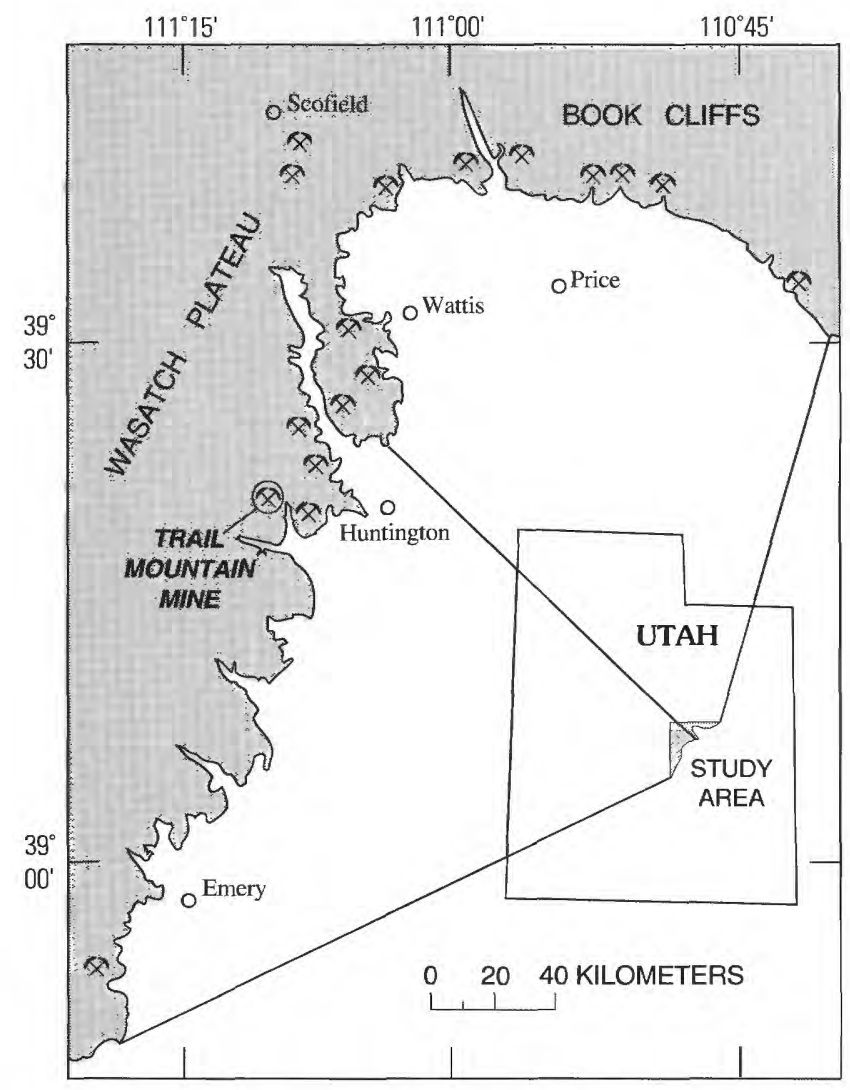

Figure 1. Index map showing location of study area in central Utah. dikes and sills and to determine their relation to processes active during and after coal accumulation. The results of this study add to the understanding of coal geology, dolomite formation, coal development and production, basin development, and shoreline processes. They also provide mining strategies for operators producing coal from seams cut by clastic dikes.

Data used in this study were collected primarily from direct examination of outcrops and mine workings, oral and written reports from local mine operators, surface and inmine drill cores, and well logs. The large number of underground mines in the study area using room-and-pillar mining methods has resulted in widely scattered threedimensional exposures along entries and crosscuts. Where mine workings were not accessible to the author because of unsafe mine conditions or because they had been sealed off following coal extraction, mine operators frequently provided photographs, samples, sketches, and detailed mine maps showing the geometry and location of dikes and sills. Continuous exposures along canyon walls provided excellent conditions for examining dikes, sills, and adjacent strata. At one location, excavation equipment was used to expose dikes for detailed examination. Drill core was used primarily to study the mineralogy and sedimentology of the floor and roof rocks; however, dikes were present in some core. Clastic material was analyzed using X-ray diffraction, cathodoluminescence, and binocular and petrographic examination. Quantitative results were determined by optical methods and by point counting 300 mineral grains per thin section.

Acknowledgments.-I am grateful for the cooperation and information provided by numerous central Utah coal companies, particularly their geology and engineering staffs. Kenneth Fleck helped to photograph and collect mine samples and provided mine expertise in the Trail Mountain mine. Mine geologists Mark Bunnell of the Skyline mine, Tom Lloyd of the Cottonwood mine, John Mercier of the Plateau mine, and Laine Adair and Mike Glasson of the Centennial mine also provided valuable information, particularly where mine workings were no longer accessible. Rodger Fry of PacifiCorp provided drill core and valuable mine data. James Cathcart and William Betterton of the U.S. Geological Survey assisted in sample analysis.

\section{DEPOSITIONAL HISTORY AND STRATIGRAPHY}

Commercial coal seams along the Wasatch Plateau and western Books Cliffs were assigned to the Upper Cretaceous Blackhawk Formation by Young (1965). These coal seams accumulated along an eastward-prograding shoreline of the Cretaceous epeiric seaway during Campanian time. Major uplifts along the Sevier orogenic belt, which extended along 
the western margin of Cretaceous foreland basin, caused pulses of terrigenous clastic material to be shed across nearby lower coastal plain and marginal-marine coastal environments (Armstrong, 1968; Balsley, 1980). Progradation, sea-level fluctuations, and lateral shifting and abandonment of coastal complexes resulted in repeated transgressive-regressive sedimentation that is recorded as a series of vertically stacked, forward-stepping, coarseningupward sedimentary packages, each of which is tens of meters thick. Typically, these packages consist of deepwater shale overlain by thick shoreface deposits and capped by coal-bearing terrestrial deposits (fig. 2). Many coal seams accumulated directly on upper shoreface deposits, as evidenced by root horizons across the upper bounding surfaces of shoreface sandstones. These rooted bounding surfaces indicate emergence of shoreface deposits prior to the development of peat swamps. Examination of core cut from shoreface deposits reveals multiple lenses of marl that range from several centimeters to more than a meter in thickness and are composed principally of detrital dolomite. During Cretaceous time, Paleozoic carbonate-rich sediments exposed along the orogenic belt were transported to depositional sites along the seaway margin (Balsley, 1980). Longshore processes redeposited these carbonate sediments along a northwest-trending paleoshoreline (Flores and others, 1982, 1984) as elongate marl lenses. Previous studies suggest that thick and continuous coal seams along the Wasatch Plateau accumulated along protected sites behind barrier islands (Young, 1965; Howard, 1969; Flores and others, 1982, 1984). Thick coal seams slightly higher in the section, exposed along the western Book Cliffs, accumulated in wave-dominated delta-plain settings (Balsley, 1980).

\section{PREVIOUS STUDIES}

Since dikes were described in central Europe by Agricola in 1556 (Hoover and Hoover, 1950), their presence in coal fields and in non-coal-bearing sequences around the world has been well documented. In a classic study, Newsom (1903) stated that coal beds are particularly favorable for the formation of clay and sandstone dikes. Although dikes are common and widespread in North American coal fields (Crane, 1898), most studies of clastic dikes and sills in coal measures are dated or of limited scope. A summary of work on clastic dikes in North American is given by Damberger (1973).

In central Utah, clastic dikes and sills were first studied by Doelling (1979) in a small and heavily mined area in the central Wasatch Plateau. Doelling proposed that dikes in the Hiawatha coal seam formed from infilled desiccation cracks in the peat. Johnson (1982), in a mine study conducted in the same study area as Doelling, concluded that surface lineaments did not appear to be directly related to the orientation or presence of clastic dikes, but he proposed no specific mode of origin. In a later study, several local mine geologists working along the northern part of the Wasatch Plateau concluded that the origin of dikes was controlled by tectonic or structural fabric (Lindberg and others, 1983). In a petrographic study of rocks collected from the Cottonwood/ Wilberg mine, a few kilometers east of Doelling's and Johnson's area, Jepsen (1987) proposed that dikes formed when desiccation cracks formed in the peat and were infilled by windborne detritus. He pointed out that desiccation cracks more than $0.6 \mathrm{~m}$ deep are present in peat beds in the Big Cypress Swamp in the southeastern United States.

Bunnell and Taylor (1987) studied clastic dikes at two widely separated mine sites in the northern part of the Wasatch Plateau. They proposed that some of the dikes in the mine workings near the town of Price (fig. 1) originated from fluvial sand bodies immediately overlying the coal but suggested no specific mode of origin. At the other mine site, about $15 \mathrm{~km}$ to the west and near the town of Scofield, they reported that dike trends are similar to regional fault trends and vertical joint planes in the coal and overlying rocks. They proposed that dike formation may be related to local tectonic activity including earthquake shocks.

\section{CLASSIFICATION OF DIKES}

Clastic dikes have been divided into three principal groups: load-compaction dikes, channel-margin dikes, and fracture-fill dikes (Hardie, 1991). Dikes within each group have a similar mode of origin and physical and compositional characteristics. On the basis of their geometry and attitude, load-compaction dikes can be further divided into pyramidal, sigmoidal, and C-shaped dikes. Clastic sills are included with load-compaction dikes because they are secondary features that formed directly from loadcompaction dikes.

\section{LOAD-COMPACTION DIKES}

\section{DISTRIBUTION}

Load-compaction dikes, with the exception of rare C-shaped dikes, are particularly abundant in an area more than $5 \mathrm{~km}$ wide in the central Wasatch Plateau that includes the Trail Mountain mine (figs. 1,3) and several nearby abandoned mine properties that produced coal from the Campanian Hiawatha coal seam. Dikes are also present, but are much less common, in mine properties about $27 \mathrm{~km}$ to the north, near the town of Wattis, and about $48 \mathrm{~km}$ to the south, north of the community of Emery (fig. 1). Dikes are present in several coal seams that span more than $60 \mathrm{~m}$ of section, although rare and poorly documented C-shaped dikes have 


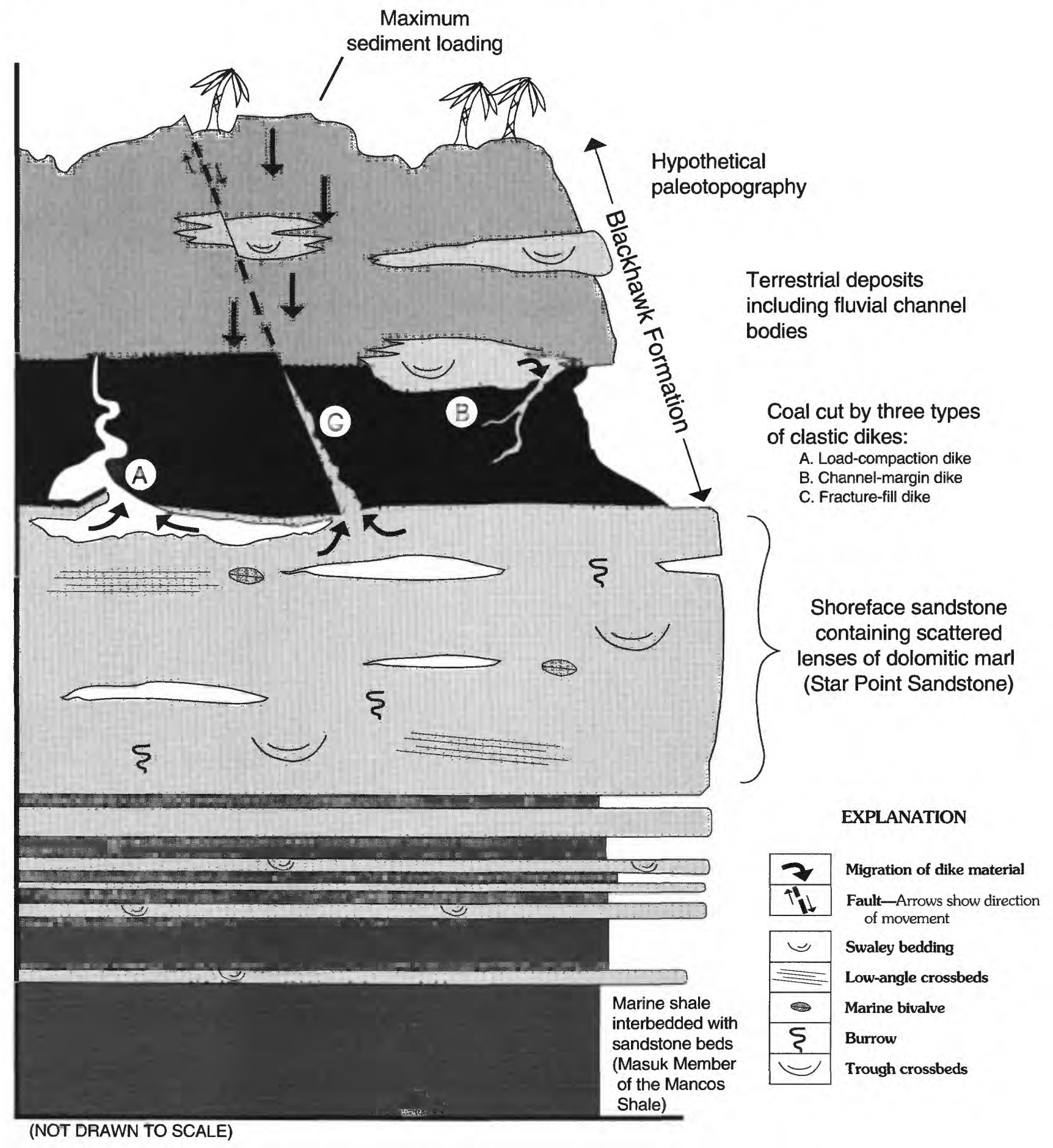

Figure 2. Schematic section showing emplacement of clastic dikes and sedimentary architecture.

been reported only in the Hiawatha seam at the Trail Mountain mine. There are no known load-compaction dikes along the western Book Cliffs. Clastic sills are common in the vicinity of the Trail Mountain mine, rare throughout most of the remaining Wasatch Plateau, and absent along the western Book Cliffs.

\section{DESCRIPTION}

Load-compaction dikes range from a few centimeters to more than $2 \mathrm{~m}$ in thickness and have been traced laterally for more than $450 \mathrm{~m}$ along mine entries and crosscuts. They penetrate all or portions of coals seams at low to high angles 


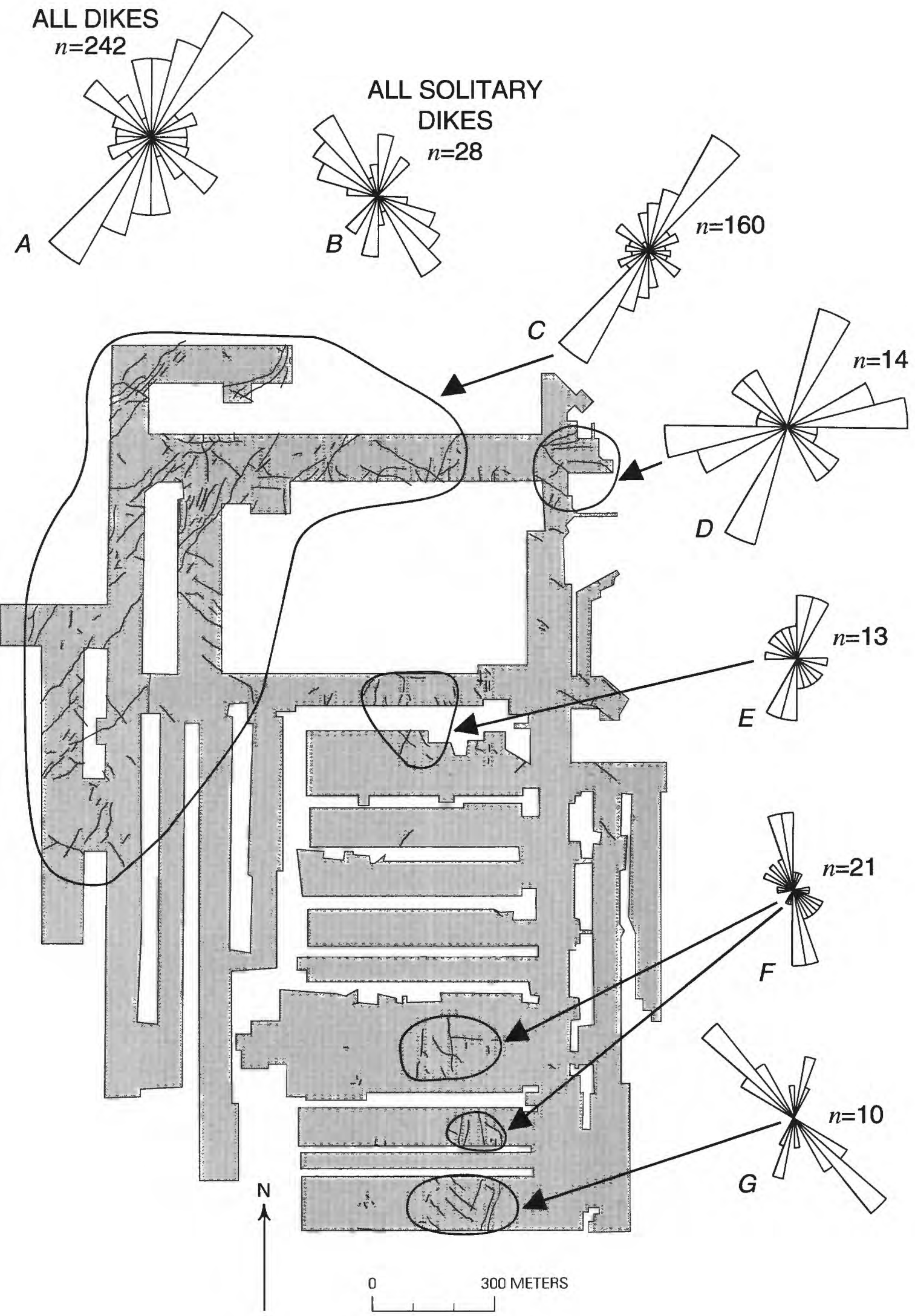

Figure 3. Drawing showing distribution and orientation of load-compaction dikes and dike swarms in the Trail Mountain mine. Rose diagrams include dikes longer than $10 \mathrm{~m}$ and are weighted by a factor of one for each hundred meters of dike length. Solid lines indicate clastic dikes; shaded areas indicate excavated mine workings. 

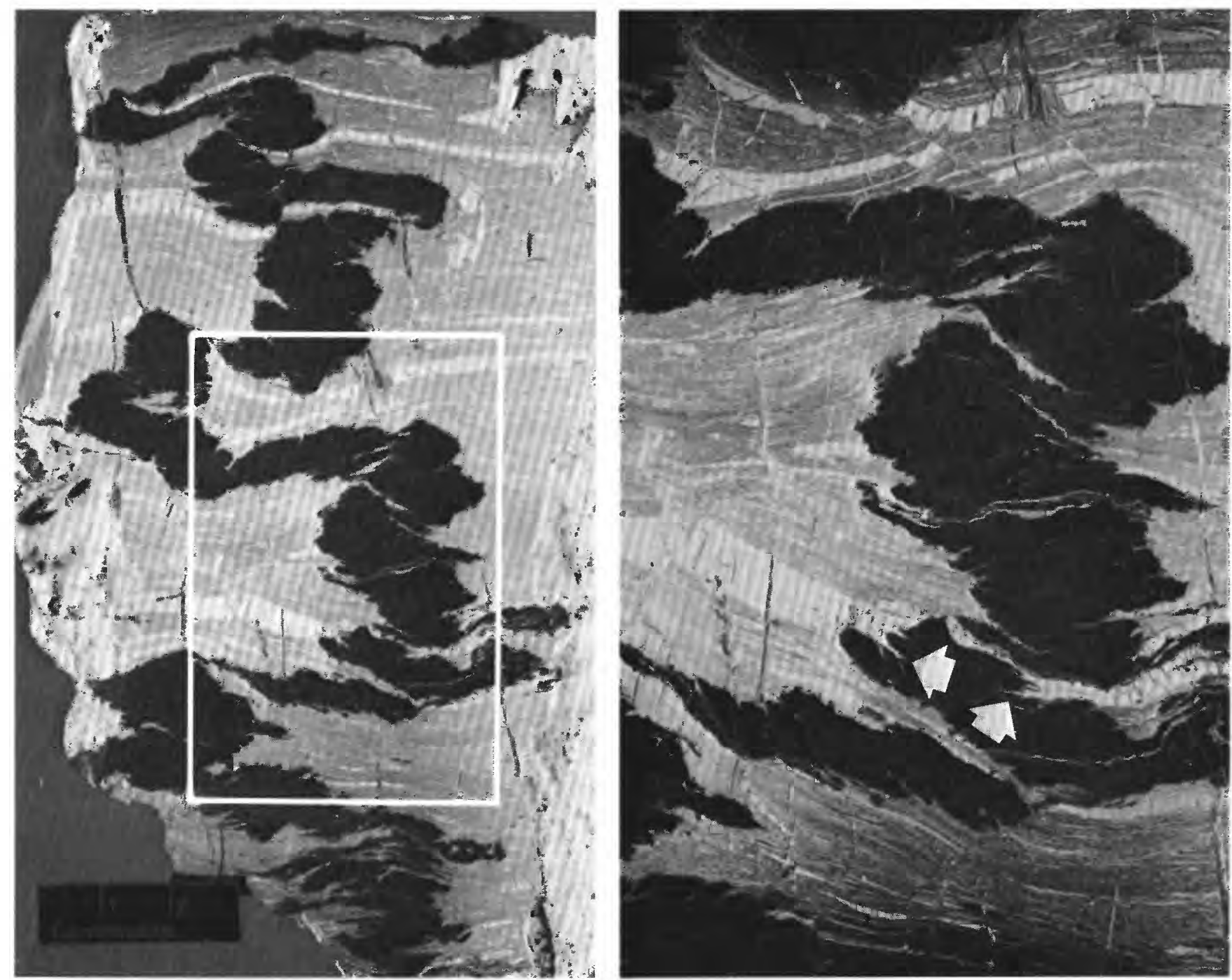

Figure 4. Negative prints of a sigmoidal dike. The photograph on the right (field, $6 \mathrm{~cm}$ by $4 \mathrm{~cm}$ ) is an enlarged view of the framed area in the photograph on the left (field, $15 \mathrm{~cm}$ by $9 \mathrm{~cm}$ ). It shows millimeter-scale faults and near-horizontal vitrain bands adjacent to dike contacts and delicate fibrous plant fragments (marked by arrows) that interfinger with dike margins.

and have a dominant central trend of N. $32^{\circ} \mathrm{E}$. and a subordinate trend of N. $50^{\circ}$ W. (fig. $3 A$ ). Dikes are present both as solitary intrusions and, more commonly, in swarms. Solitary dikes have a dominant trend of $\mathrm{N} .40^{\circ} \mathrm{W}$. and a subordinate trend of N. $10^{\circ}$ E. (fig. $3 B$ ). Swarms are as closely spaced as $200 \mathrm{~m}$ apart and cover areas that range from less than $150 \mathrm{~m}$ to more than $1,000 \mathrm{~m}$ in width (fig. 3). Individual swarms range from less than 10 to more than 150 dikes and include both pyramidal- and sigmoidal-shaped dikes and commonly clastic sills. The central trend of dikes within individual swarms generally varies from one swarm to another as shown in figures $3 C-G$. Coal cleat, oriented roughly N. $65^{\circ}$ E. and N. $15^{\circ} \mathrm{W}$., can be traced cutting across the entire thickness of some dikes. Dikes, particularly those that are massive, are commonly cut by several medium- to highangle faults that have offsets that measure from less than a centimeter to as much as $20 \mathrm{~cm}$.
Dike contacts range from smooth to finely serrated to coarsely jagged. Where contacts are smooth, dikes are bound by numerous sets of slickensides that are generally oriented parallel to subparallel to the direction of dike shortening. Jagged contacts are composed of a series of crude wedgeshaped projections of interfingering coal and dike material. Detailed impressions of sticks and other coarse vegetable matter, some showing the texture of their bark, are fairly common along the subhorizontal surfaces of individual projections. The coal along the margins of dikes is commonly cut by hundreds of millimeter- to centimeter-scale faults (fig. 4). In some exposures, bright vitrain bands are bent strongly upward near dike margins; however, in others, banding is almost horizontal. Examination of the polished block of dike material and coal shown in figure 4 confirmed the presence of horizontal to low-angle coal layering adjacent to the margins of some dikes. Figure 4 also shows that the delicate 

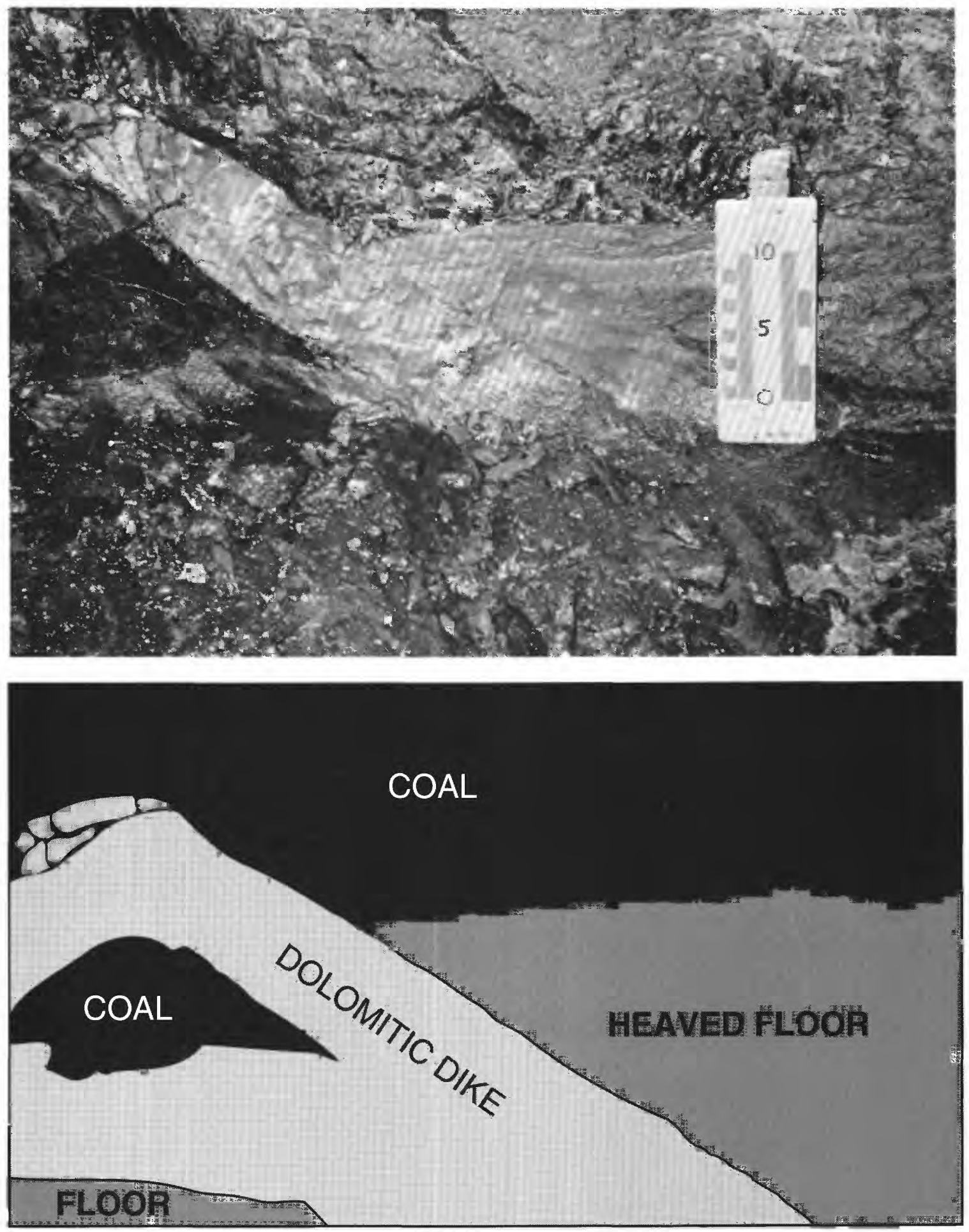

Figure 5. Photograph and schematic drawing showing sandstone floor rock of the Star Point Sandstone cut and heaved by a low-angle dike. 

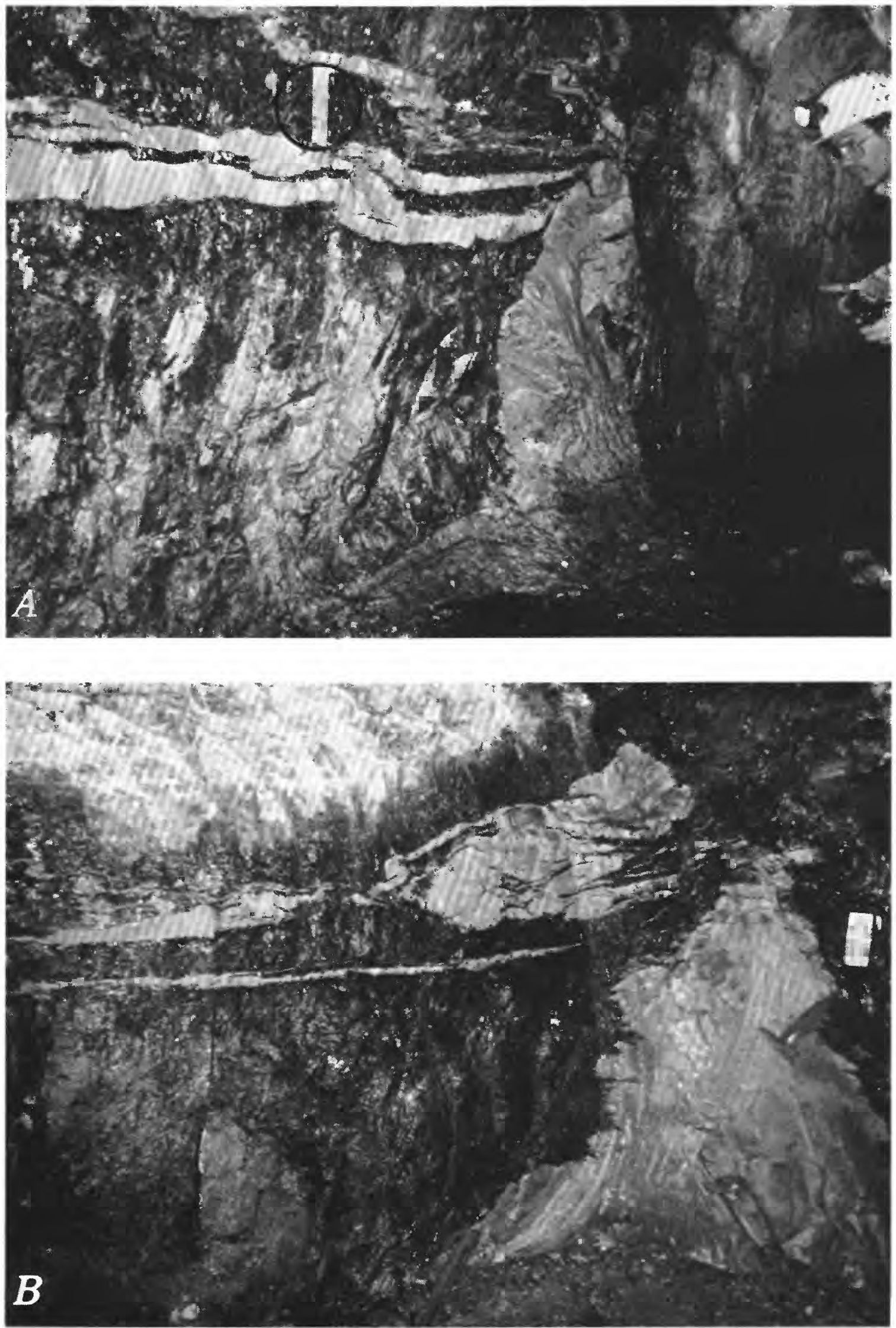


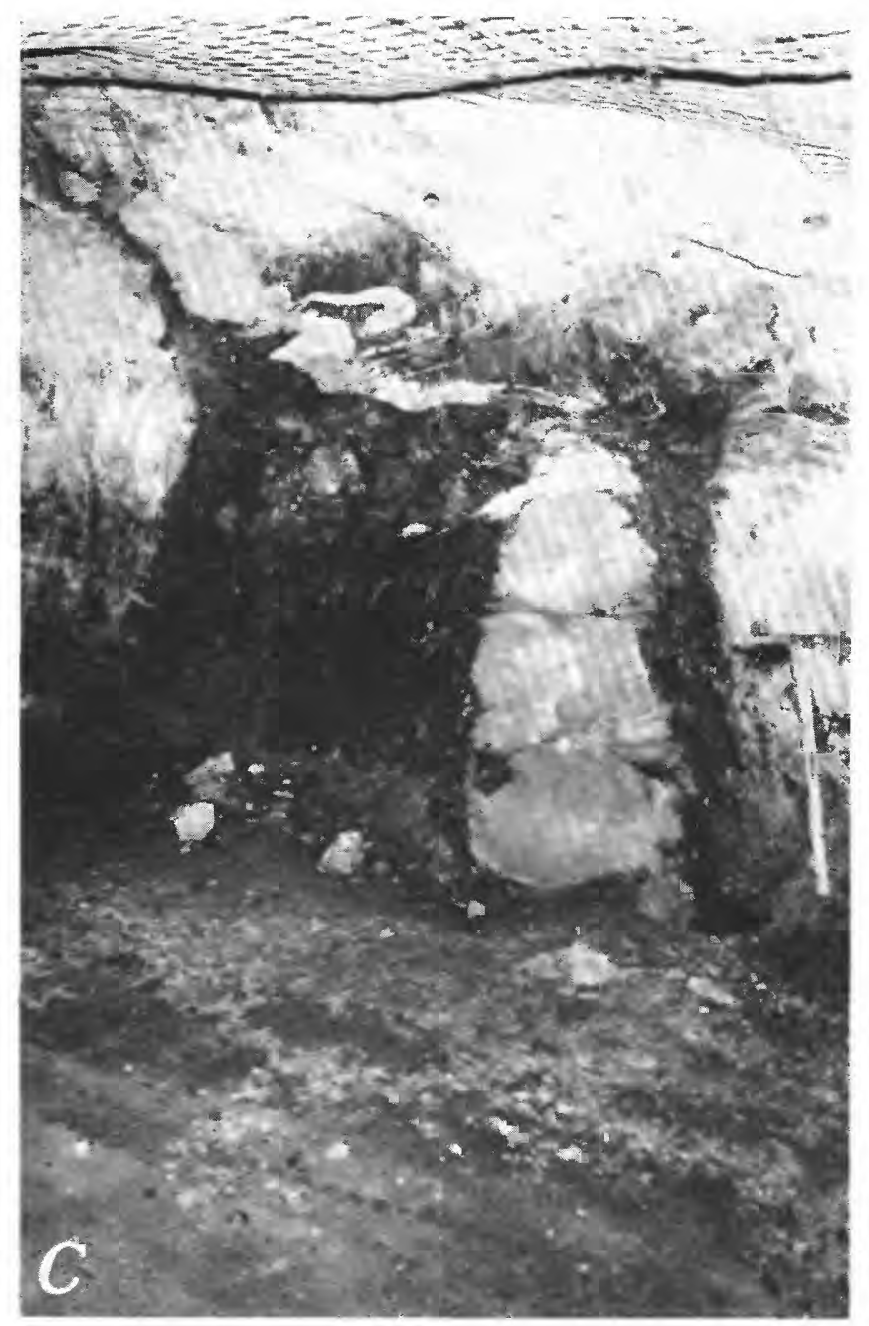

Figure 6 (above and facing page). Pyramidal-shaped dikes with different forms of secondary injection features attached to their termini. Scale cards (circled) in $A$ and $B$ are $15 \mathrm{~cm}$ high and the pick in $C$ is about a meter high.

coalified fibrous plant material that penetrates the margins of dikes is roughly horizontal to low angled and approximately perpendicular to the direction of dike shortening. Examination of some thin sections of dike contacts shows a similar orientation of fibrous plant material.

Dike material is composed of light- to medium-gray, well-indurated, sandy dolostone. In some dikes, irregularshaped clasts or plugs of claystone and shale more than 10 $\mathrm{cm}$ across appear to be lodged in narrow portions of dikes. Fresh exposures of dike material commonly reveal two types of flow structures, circular swirls and less common laminar structures, both composed of alternating light and dark material produced by differences in grain size. Concentric swirls, approximately a centimeter or more across, commonly are present in massive dikes, where they produce a mottled appearance. Laminar flow structures rarely are more than $5 \mathrm{~mm}$ thick and are composed of very thin laminae that alternate between light- and dark-gray rock. Laminae are generally oriented parallel to the lower contact of lowangle dikes and sills and follow smoothly and evenly around irregularities along dike contacts.

In rare mine exposures, coal-cutting equipment has exposed sandstone floor rocks that are offset as much as $2 \mathrm{~cm}$ on either side of dikes that cut through the floor rock and into the base of the coal. Figure 5 shows one such exposure where the floor rock directly above the inclined dike is offset more than $15 \mathrm{~cm}$ above the adjacent floor rock on the opposite side of the dike. Examination of thin sections cut from the dike material and from the floor rock on either side of the dike shows contrasting mineralogy. The floor rock is composed of typical quartzose Star Point Sandstone, whereas dike material is composed of approximately 65 percent dolomite and 35 percent quartz, chert, and feldspar. In the sandstone floor rock along the dike-floor contacts are scattered pockets of microcrystalline dolomite that measure from several millimeters to roughly a centimeter in width and display well-defined laminar flow structures accentuated by streaks of organic-rich material.

\section{PYRAMIDAL-SHAPED DIKES}

Pyramidal dikes are common intrusions that measure from about $30 \mathrm{~cm}$ to more than $2 \mathrm{~m}$ thick at their base and rapidly taper to a terminus about $1-2 \mathrm{~m}$ above the floor. Attached to their termini are various forms of secondary injection features that include sills and discordant contorted bodies of clastic material such as those shown in figure 6 . Dike contacts range from almost smooth to jagged. Where contacts are jagged, fishtail-shaped projections of coal as thick as several centimeters commonly penetrate the margins of dikes.

\section{SIGMOIDAL-SHAPED DIKES}

Sigmoidal dikes are common features that are present as crenulated ribbonlike bodies that cut through most or all of coal seams at medium to high angles. High-angle dikes, those greater than about $70^{\circ}$, display complex geometries that are intensely crenulated and highly faulted and swollen (fig. 4). In rare exposures, sills extend laterally for tens of meters from the outside radius of sharp folds in high-angle dikes (fig. 7). Dikes are generally less than $20 \mathrm{~cm}$ thick and taper toward the roof; however, in one exposure where heavy equipment was used to excavate the lower part of an average-size dike, the base of the dike abruptly flared to more than $2 \mathrm{~m}$ across within about $15 \mathrm{~cm}$ of the sandstone floor rock. Such thickening suggests that sigmoidal dikes may grade into pyramidal dikes. Where dikes are present in swarms, they commonly cut adjacent dikes at various angles to form complex interconnected networks. Dikes have been traced laterally along the roofs of mine entries, where they abruptly split into two or more diverging branches. Some sigmoidal dikes cut into the roof rock where they generally 


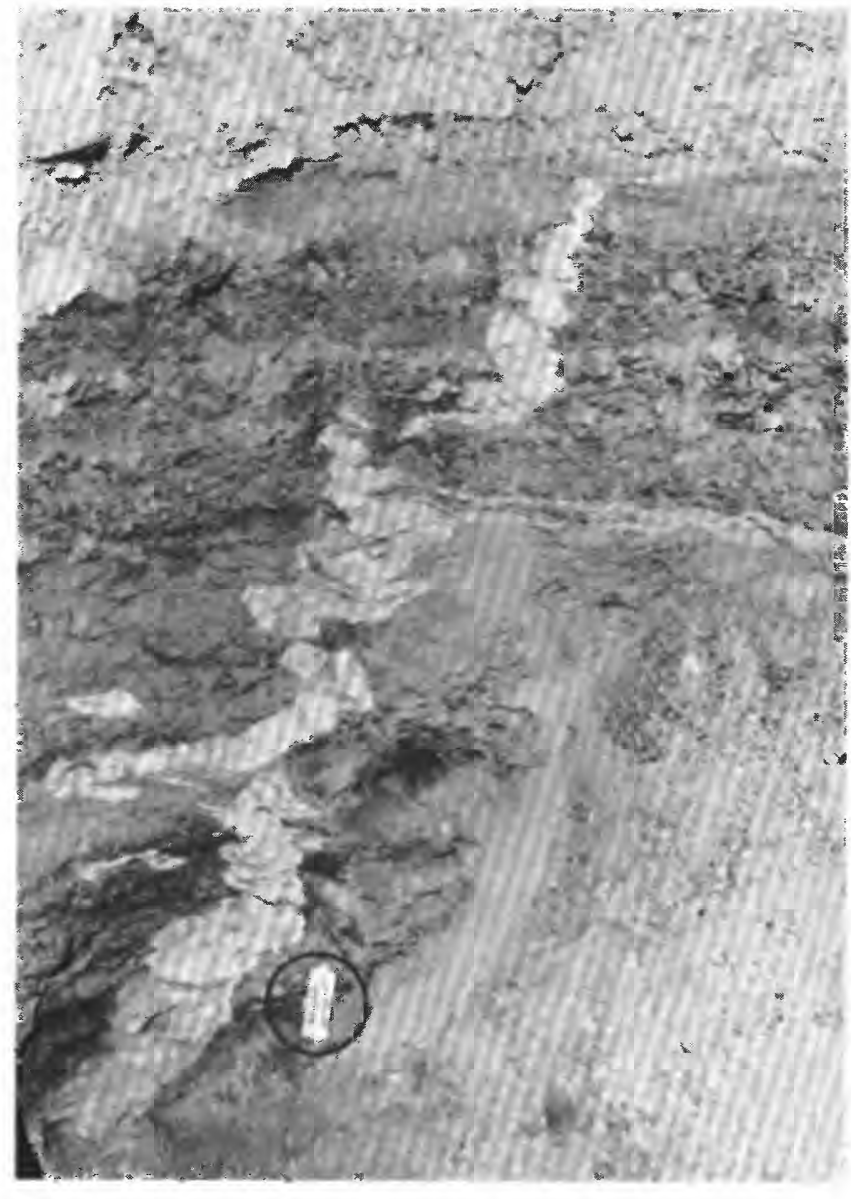

Figure 7. Sigmoidal-shaped dike with sill attached to the outside radius of a sharp fold. Scale card (circled) is $15 \mathrm{~cm}$ high.

taper and pinch out within a few centimeters of the coal-roof contact. Here, just beneath the roof line, they abruptly swell to as much as four times their normal thickness, then abruptly thin at the point where they enter the roof rock. In other exposures, particularly where the roof rock is composed of well-indurated organic-rich claystone, dikes penetrate only to the base of the roof rock, where they become highly swollen and create convex-upward depressions along the coal-roof contact that measure many centimeters across.

\section{C-SHAPED DIKES}

When viewed in cross section, C-shaped dikes are tabular bodies that are shaped like a broad and crudely formed C (fig. 8). They range in thickness from about $15 \mathrm{~cm}$ to $40 \mathrm{~cm}$, but their thickness varies greatly when traced from floor to roof. Dikes appear to cut entire coal seams; however, poor exposures conceal their affinity with floor and roof rocks. Dikes are sharply bound and commonly display bulbous irregularities along their contacts that are caused by uneven distribution of dike material.

\section{SILLS}

Sills are fairly common in areas where pyramidal dikes are present and are less common where sigmoidal dikes are found. They are typically attached to the terminus of pyramidal dikes (fig. 6A) and to the outside radii of tight folds in sigmoidal dikes (fig. 7). Sills are as thick as $10 \mathrm{~cm}$ and can extend laterally for more than $100 \mathrm{~m}$. They are generally present in multiples of from 2 to 10 closely spaced sills in the lower half of coal seams (fig. 9). They have sharp contacts and where traced laterally display fairly uniform thicknesses, with the exception of an occasional bulbous area that is swollen with sill material. Millimeter-scale, lowto medium-angle dikes commonly connect a thick sill with one that is considerably thinner. It is likely that thicker sills provided clastic material for the development of thinner ones. Well-defined millimeter-scale laminar flow structures are common along the lower contact of sills.

\section{MINERALOGY}

Forty-two stained and unstained thin sections representing dike and sill material, coal-seam floor and roof rock, and marl were analyzed petrographically. Because of the heterogeneity of dike material observed in the thin sections, large samples from which the thin sections were cut were analyzed by X-ray diffraction to determine bulk mineralogy. Seven samples were examined using cathodoluminescence.

Dike material consists of heterogenous dolostone containing scattered millimeter- to centimeter-scale pockets and stringers of quartz and (or) dolomite grains that are generally of a different grain size than that of the host rock. Clastic material can be either matrix- or grain-supported and is composed of 46-85 percent dolomite, 9-44 percent quartz, 2-6 percent feldspar, and trace amounts of chert and lithic fragments of sedimentary origin. Although generally absent, where present calcite rarely exceeds $2-3$ percent. Dolomite is present in at least four forms that include 2-6 percent of total dolomite content as partially replaced feldspar grains, 3-9 percent as cement, 1-12 percent as aggregate detrital grains, and 42-78 percent as monocrystalline detrital grains. Feldspar grains are abraded and partially altered to dolomite. Dolomite cement is iron-rich anhedral pore fill that has eliminated any visible porosity. Subrounded to wellrounded aggregate dolomite grains are poorly to well sorted polycrystalline and range from less than 50 to more than $300 \mu$ in diameter. Individual component grains of dolomite are poorly to well sorted, rounded to well-rounded grains that range from less than 10 to $100 \mu$ in diameter. Monocrystalline dolomite grains rarely exceed $250 \mu$ in diameter and are generally poorly sorted and rounded to well rounded. Grains commonly display optically continuous ferroan rims; however, minor euhedral to subhedral grains ranging from 


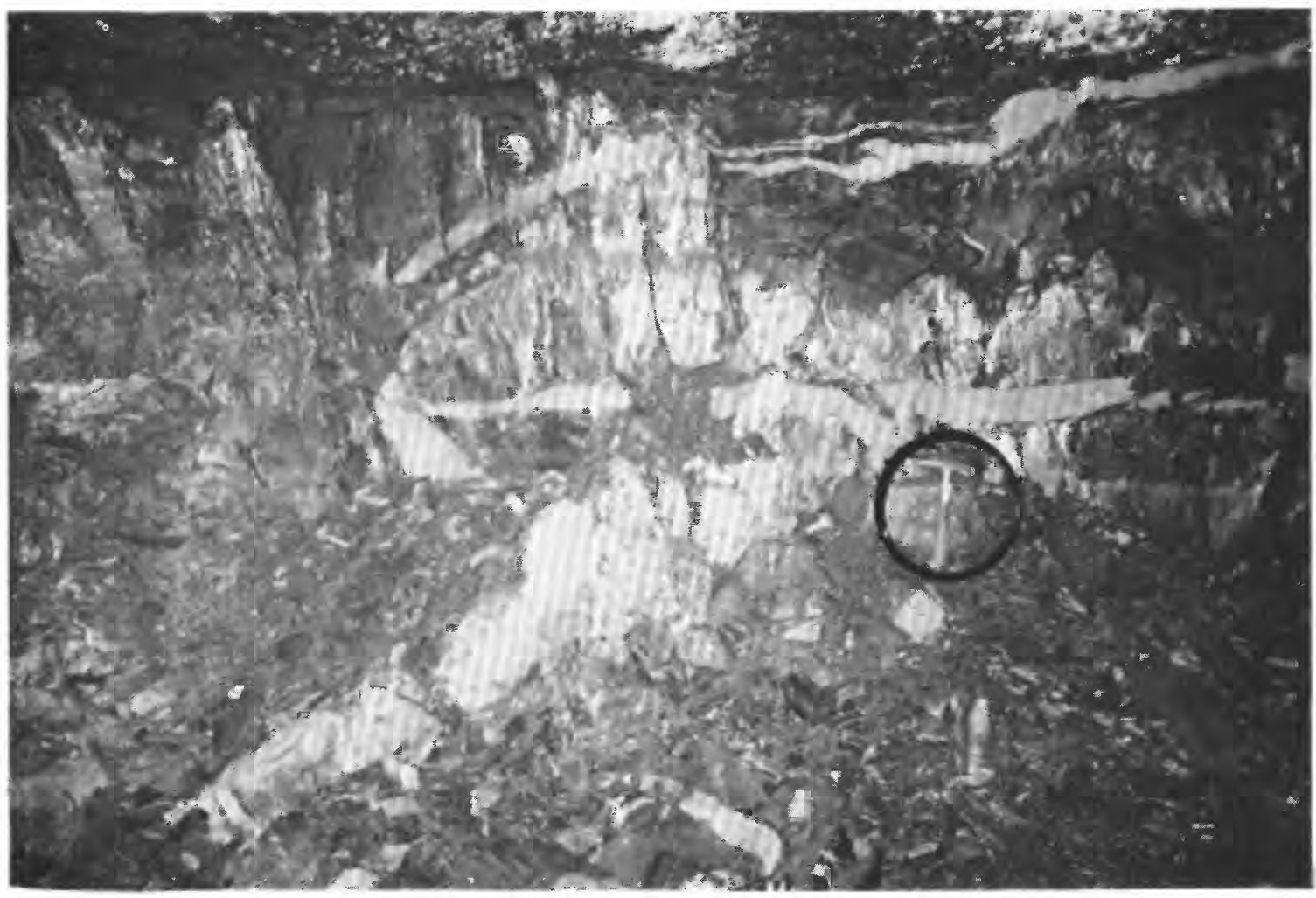

Figure 8. C-shaped dike in the Hiawatha coal seam. Rubble is in area beneath hammer (circled).

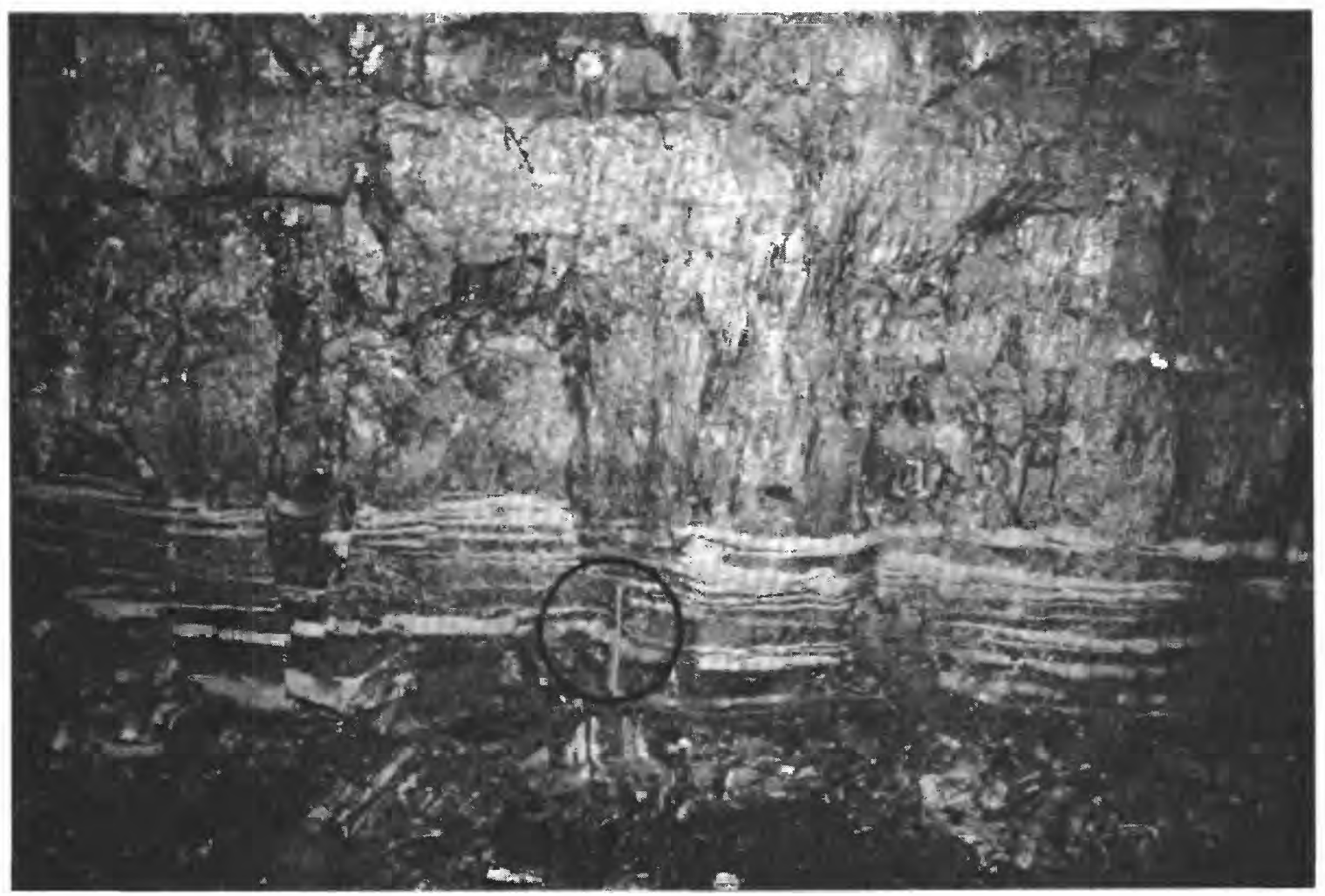

Figure 9. Multiple clastic sills near base of a coal seam. Hammer (circled) is shown for scale. 


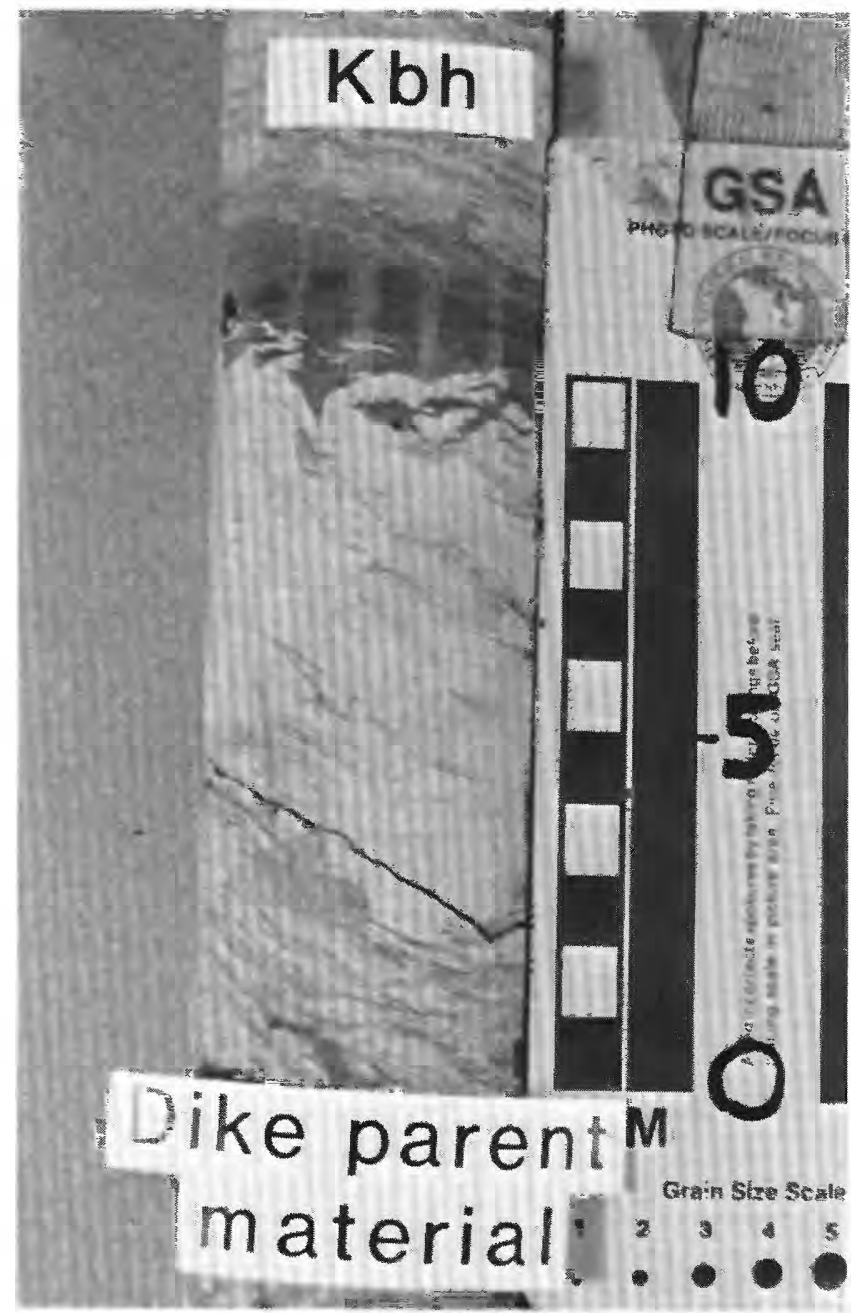

Figure 10. Core containing small-scale dikes at the top of a marl lens $1.5 \mathrm{~m}$ below the base of the Hiawatha coal seam in the Star Point Sandstone.

sharp-edged to slightly abraded rhombs also are present and may be incorrectly grouped with detrital material. This variation in grain angularity suggests variable reworking of dolomite grains. Under cathodoluminescence, some rounded grains contain well-defined cores; however, the fact that slightly abraded to sharp-edged dolomite rhombs do not contain such cores suggests that euhedral grains did not form from secondary overgrowth of detrital cores but that entire grains precipitated at sites nearby. Highly fractured dolomite grains that are iron stained along their fractured edges are common and probably resulted from postdepositional compaction followed by contact with iron-bearing magnesium-rich fluids. Individual pockets and stringers of clastic material, commonly seen in thin section, display a narrow range of grain sizes; however, within a single dike, different stringers and pockets display grain diameters that range from microcrystalline to more than $300 \mu$.

Petrographic examination of marl lenses, cored from depths ranging from a few centimeters to more than $40 \mathrm{~m}$ below the base of the coal seams, shows that the marl is similar in composition to dike material. Marl is composed of 31-75 percent dolomite, $18-58$ percent quartz, 4-9 percent feldspar, and trace amounts of chert and lithic fragments. The four forms of dolomite in the dike material are present in similar quantities in marl lenses. The major difference between the two types of rock is that the marl is homogenous, lacking the stringers and pockets of sedimentary material common in dikes. It is interesting that small centimeterscale dikes were found at the top of a cored marl lens, approximately $1.5 \mathrm{~m}$ beneath the top of the Upper Cretaceous Star Point Sandstone (fig. 10).

About $300 \mathrm{~m}$ east of the main portal at the Trail Mountain mine, a narrow westerly trending lens-shaped sandstone body, interpreted by local mine geologists as a possible washover fan, was scoured into the top of the Star Point Sandstone and is overlain by the Hiawatha coal seam. Petrographic examination of the fine-grained rock along the margins of the lens shows that the sedimentary material has a composition very similar to that of the dike material.

Sill material is composed of more than 90 percent ironrich microcrystalline dolomite and minor amounts of fine- to medium-grained detrital quartz and dolomite grains.

\section{INTERPRETATION}

Intense folding, swelling, and faulting of high-angle sigmoidal dikes indicates that they were injected early, prior to significant compaction and decomposition of the peat. A compaction ratio of four to one was determined for a sigmoidal dike; its height was restored by outlining its margins with a string and then measuring the length of string. This ratio does not, however, include the amount of height that was lost through faulting, dike swelling, and lateral migration of clastic material. The fibrous character of plant material along dike margins and the well-preserved impressions of bark texture along dike contacts show that time was insufficient for significant decomposition of plant material to occur. In a study on coal metamorphism, Teichmuller and Teichmuller (1968) stated that the detailed features of initial plant material are often recognized in peat but are not recognizable in rank stages from soft brown coal and beyond. The presence of cleated dikes and the absence of coal cleats filled with dike material indicate that dikes formed prior to cleat development. Close (1991) estimated that cleat development in Cretaceous coals occurred within 4 m.y. of peat accumulation in the northern San Juan Basin and within 1.5-5.8 m.y. in the Raton Basin. Although it is widely accepted that cleat development is interdependent on many factors (Close, 1992), if one accepts Close's figures as an approximate reference frame for coal cleat development in central Utah coals, then dikes formed within roughly 6 m.y. of peat accumulation.

Several lines of evidence demonstrate that dike material was injected from below. Mine exposures showing floor 
rocks that have been cut by dikes and that are offset on either side of the dikes leave little doubt that injection was from below. Here, pressure beneath the floor caused by the upward migration of dike material probably caused the floor to heave directly above the dike. The offset fracture created along the floor rock provided an avenue for the dike material to penetrate into the base of the peat. Further evidence for injection from below includes convex-upward depressions, interpreted as pressure points, along coal-roof rock contacts just above the terminus of some dikes and dikes that are swollen just below the roof rock contact. Here, the upward migration of dike material was probably impeded at the base of resistant roof sediment, resulting in dike swelling and the formation of pressure points along the roof line. The abundance of dikes that taper upward and that pinch out before reaching the roof of coal seams is further evidence that injection was from below.

Dike material was derived from multiple sources within the Star Point Sandstone. The composition of typical Star Point Sandstone and of the Masuk Member of the Upper Cretaceous Mancos Shale (Davis and Doelling, 1977; Jepsen, 1987), as compared to that of dike material, precludes either unit as a possible source. Petrographic analysis of cored marl lenses from within the Star Point Sandstone shows, however, that dike material and marl are almost identical both mineralogically and petrologically. Mine exposures where the sandstone floor rocks are offset along dikes that cut into the base of the coal demonstrate that the source material is at least $15 \mathrm{~cm}$ below the top of the Star Point Sandstone. In addition, centimeter-scale dikes at the top of cored marl lenses possibly are small-scale clastic dikes that failed to develop into larger forms. The presence of dikes in swarms suggests that multiple marl lenses within the Star Point Sandstone provided clastic material for dikes. Individual or several closely spaced dike swarms within the same area are believed to correspond to an isolated body of marl.

Injection of dike material was probably a gradual or intermittent process that did not occur everywhere at the same time as evidenced by the crosscutting relations of some dikes. In addition, the heterogeneity of dike material, including the presence of parallel laminar flow structure recognized in thin section, suggests a less than violent injection process. Hesse and Reading (1978), in a study on clastic dikes in non-coal-bearing strata, recognized similar flow structure and suggested that the extrusion of sediments took place in a laminar fashion but may have been more violent in the case of homogenized dike material. They pointed out, however, that if injection were sudden and violent the rate of flow of clastic material probably would have waned some time after the initial triggering event and produced features indicative of gradual migration of clastic material.

The attitude of vitrain bands and the jagged interfingering projections of coal along some dike contacts suggest that dike material migrated both laterally and vertically through the peat. Where jagged projections are turned up and vitrain bands are sharply bent upward, dike material was probably injected vertically. The drag between migrating clastic material and the peat resulted in deformation of both banding and interlayered projections. Where coal banding and interfingering coal are relatively horizontal and undisturbed, dike material probably migrated laterally. Fine and delicately interlayered primary plant components that interfinger with dike material (fig. 4) suggest that these were sites of lateral migration. It is reasonable that the path of migration was both vertical and horizontal during the injection process. Another possibility is that dike material was a low-viscosity slurry of mostly water and minor suspended detrital grains that imposed little drag on plant material.

Sills are secondary features that formed from dikes. The common occurrence of sills that are physically attached to the termini of pyramidal-shaped dikes and to tight folds of high-angle sigmoidal dikes demonstrates that sills formed from dikes. Their sharply bound concordant contacts along coal bedding planes and their well-preserved laminar flow structure indicate that dike material advanced along horizontal zones of weakness within the peat. Elliott's (1965) classification of subaqueous sedimentary structures designates laminar flow structures as horizontal transposition structures whose geometry suggests that the sediments were subject to lateral extension. Furthermore, sill material is almost identical in composition to dike material.

\section{DISCUSSION}

Although the origin of load-compaction dikes is not completely understood, the principal driving force responsible for mobilization of carbonate-rich sediments is gravity acting on the sediments overlying lenses of marl. Other factors, including irregularities along the surface of accumulation, overpressuring of the Star Point Sandstone, and the channeling of water from the underlying marine shale, probably played a role in dike development. Kerns (1970) proposed that dikes in the Pittsburgh coal seam in southern Pennsylvania were mainly controlled by vertical stress and differential compaction. Vertical stress caused by the weight of overlying sediments, acting uniformly across a lens of water-saturated marl, would pre-load the lens (Athy, 1930), but the sediments would remain in place. Uneven load stress caused by paleotopography could cause a portion of the lens to collapse where load stress was high, squeezing out the dike material as in pinching a tube of toothpaste (fig. 2). The Star Point Sandstone that surrounds the marl lenses probably acted as a resistant barrier that directed the migration of dike material upward, toward low-pressure sites along the base of peat beds. Sites where dike material entered the base of peat beds may have been controlled by 
irregularities along the depositional surface of peat accumulation (Wilson, 1916). Local irregularities along the base of the Hiawatha coal seam at the top of the Star Point Sandstone may have formed from the development of runnels and surge channels (Johnson, 1979). These linear irregularities probably formed laterally extensive pressure points along the base of the peat where tears or zones of weakness formed that later became low-pressure sites for the migration of dike material. If the Star Point Sandstone was overpressured and if the plant matter and hydrostatic pressure within the peat swamp were adequate to provide a seal, release of overpressure may have aided in dike formation. It is reasonable that either increasing pressure within the sandstone or decreasing hydrostatic pressure in the peat reached a critical point at which the overpressure was vented upward into the base of the peat. Dewatering of the marine shale beneath the Star Point Sandstone probably aided injection by providing a prolonged source of water to maintain the mobility of the marl slurry. In addition, the upward migration of water may have established preferred avenues through the peat, similar to that of springs or boils in peat bogs (Bennett and others, 1991), that later became avenues for dike material.

Dike location and possibly orientation were controlled by longshore processes. Carbonate-rich sediments were transported by streams to depositional sites along the Cretaceous seaway (Balsley, 1980). Longshore drift currents probably redeposited these sediments (Flores and others, 1982) in elongate bodies oriented parallel to subparallel with the paleoshoreline. The presence of marl lenses within the shoreface sandstone shows that dolomite was redeposited under shallow-marine conditions. Although the N. $10^{\circ}-20^{\circ} \mathrm{W}$. paleoshoreline trend proposed by Flores and others (1982) only partly agrees with principal dike trends shown in figure 3 , the lack of more convincing alignment may reflect local irregularities in the paleoshoreline. Probably the most widely favored modes of origin for clastic dikes in coal beds are infilling of desiccation cracks (Cady, 1942; Doelling, 1979; Jepsen 1987), dike formation controlled by structural trends (Linderg and others, 1983; Hardie, 1992; Hardie and Bostick, 1993), and intrusion resulting from seismic shocks from earthquakes and (or) volcanic activity (Gresley, 1897; Crane, 1898; Kendall, 1919; Raistrick and Marshall, 1939; Shirley, 1955; Williamson, 1967; Damberger, 1973; Doelling, 1979). Dike formation attributed to desiccation cracks requires sufficient dehydration of peat to develop large wedge-shaped cracks that are later infilled from above by subaerial processes (Doelling, 1979; Jepsen, 1987). Although large dissection cracks more than $60 \mathrm{~cm}$ deep have been reported in peat beds in the Everglades National Park (Jepsen, 1987), the load-compaction dikes in the study area were clearly injected from below. Pyramidshaped dikes have broad bases that pinch out in an upward direction some distance below the roof rock. This upward pinchout is inconsistent with infilled desiccation cracks that are widest at the surface and narrow downward. In addition, the formation of desiccation cracks requires considerable drying of the peat, which would have produced oxidized zones not observed in Utah coal seams. Dike formation related to local or regional structural trends is unlikely because of the wide range of dike trends shown in figures $3 B-G$. Results of a similar study conducted in the Piceance Basin of western Colorado (Hardie, 1992; Hardie and Bostick, 1993) show that dikes in Cretaceous coals are structurally controlled and cited as one of the principal lines of evidence, the narrow range of dike trends corresponding to joint sets in the coal floor rock. In the case of the Trail Mountain mine, however, a comparison of the trends of all loadcompaction dikes (fig. $3 A$ ) with structural trend data (fig. 11) shows that the axis of the Straight Canyon syncline, located less than $2 \mathrm{~km}$ northwest of the mine property, is roughly parallel with the dominant trend of dikes. It is noteworthy that the coal cleat trends shown in figure 11 , widely accepted as a strong indicator of tectonic stresses present during early coalification, do not appear to be related to the dominant N. $32^{\circ}$ E. trend of the dikes. Dike formation resulting from seismic shock is not likely, although seismic activity was probably present, given the proximity to the nearby cordillera. Genesis by seismic shock implies sudden and violent injection facilitated by thixotropic behavior of watersaturated sediments. Load-compaction dikes form less suddenly. Seismic shock commonly produces crustal deformation features over wide areas, particularly if the area affected is near a coastline. For example, Foster and Karlstrom (1967) reported that during the 1964 Alaskan earthquake crustal deformation, including widespread outpourings of mud and sand, pressure ridges, mounds, fissures, collapsed pits, mud and sand surface flows, and slump features, occurred over an area more than $100 \mathrm{~km}$ across but was most common along coastal settings, such as mud flats. Similar features covering more than $10,500 \mathrm{~km}^{2}$ formed during the New Madrid earthquake series (Saucier, 1977), and earthquake deformation occurred in an area of roughly $18,304 \mathrm{~km}^{2}$ during an 1869 earthquake in eastern India (Oldhan and Mallet, 1872). In the vicinity of the Trail Mountain mine, sedimentologic features that could be interpreted as earthquake deformation features, other than dikes and scattered exposures exhibiting convolute bedding, are rare to absent. In addition, the areal distribution of load-compaction dikes is not characteristic of widespread deformation induced by seismic shock. Dikes are limited to three small, widely separated areas along the Wasatch Plateau. In the vicinity of the Trail Mountain mine, dikes are absent less than $2 \mathrm{~km}$ to the south in the abandoned Black Diamond mine, less than $2 \mathrm{~km}$ to the east in the Cottonwood mine, about $5 \mathrm{~km}$ to the north in the Deer Creek mine, and in 


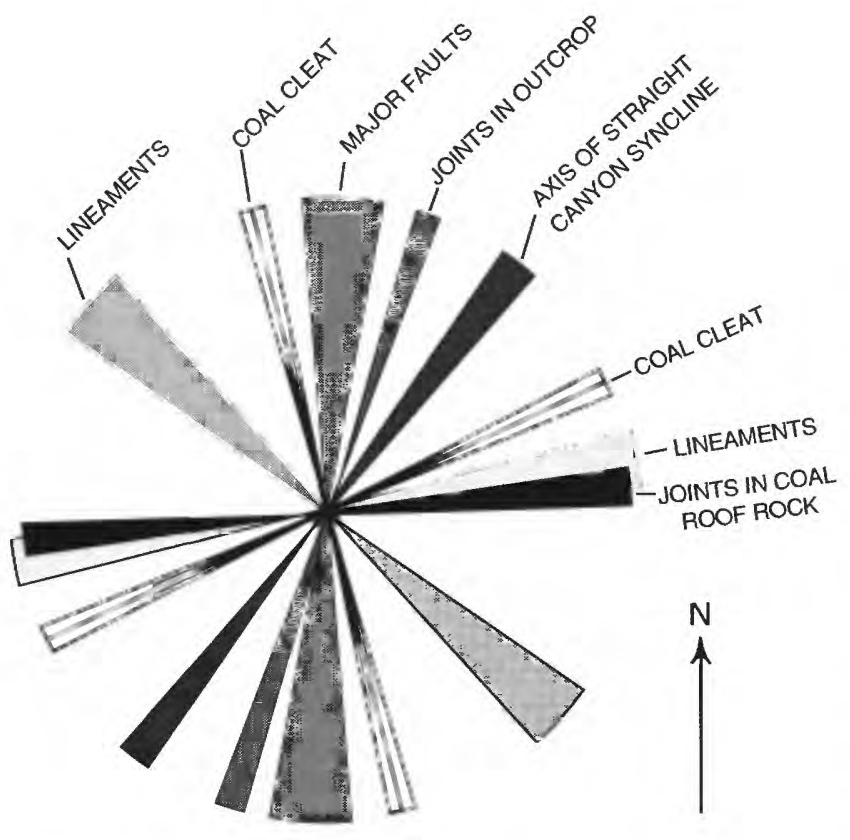

Figure 11. Trends of structural elements and related features in the vicinity of the Trail Mountain mine. Range of trends indicated by width of vector segments. Data from Davis and Doelling (1977), Johnson (1982), and local mine operators.

recently opened mine workings on the western margin of the Trail Mountain mine. In addition, the near absence of dikes that pinch out farther than about $30 \mathrm{~cm}$ into the roof rock is inconsistent with earthquake-related eruptions of sand and water, which commonly breach the surface in the form of violent sandblows or outpourings of mud that form large pools along the surface. Furthermore, it is hard to imagine that broad C-shaped dikes in coal and parallel laminar flow structures in dike material that wrap smoothly around sharp irregularities along dike-coal contacts would form from a sudden seismic event. It is possible, however, that a small-magnitude earthquake (or series of earthquakes) could have released sufficient energy to trigger the formation of dikes that failed to breach the surface.

Attempts have been made by the author and by other investigators to determine peat-compaction ratios based on restoration of crenulated dikes to their original heights. Caution should be exercised when applying these data because the ratios do not measure peat compaction that was assimilated through dike swelling, faulting, and lateral migration of dike material from the original site of injection. Furthermore, ratios may be an extremely poor measure of peat compaction if they were determined from dike crenulation produced during the lateral migration of dike material along irregular planes of weakness some distance from the original point of vertical injection.

\section{CHANNEL-MARGIN DIKES}

\section{DESCRIPTION}

Channel-margin dikes are present in small numbers in almost all coal mines throughout the Wasatch Plateau and western Book Cliffs and appear to be randomly oriented. These dikes are probably more abundant than previously reported because they are generally small-scale features that have little impact on coal production and are often ignored by mine personnel. Dikes are present both in swarms and as solitary intrusions in at least 10 major coal seams that span more than $250 \mathrm{~m}$ of section that includes the Hiawatha seam. They are commonly attached to sandstone channel bodies in the roof (fig. 12) and in rare cases are attached to sandstone rolls in the floor. Channel-margin dikes rarely exceed $5 \mathrm{~cm}$ in thickness, can extend more than $100 \mathrm{~m}$ laterally, and generally taper downward to a terminus within the upper meter of coal seams. High-angle dikes, greater than about $50^{\circ}$, display a poorly developed crenulated character and have slightly jagged margins. Low-angle dikes have more uniform thicknesses and display almost smooth contacts. Dikes attached to channel bodies commonly can be traced downward for $10-20 \mathrm{~cm}$, at which point they change to a horizontal direction, parallel with the base of the channel body. The margins of channel bodies that are attached to dikes are commonly outlined by vitrain bands that conform with the general shape of the channel. Results of petrographic analysis and X-ray diffraction show that individual dikes and their companion channel sandstone body are indistinguishable in composition. They are composed of grain-supported quartzose sandstone with dolomite and (or) calcite cement.

Dikes that emanate from floor rolls share the same characteristics as those associated with roof channels except that they are smaller and have shallower penetration. They rarely exceed a few centimeters in thickness, penetrate less than $0.5 \mathrm{~m}$ into the base of coal seams, and extend laterally less than $100 \mathrm{~m}$. Mine operators along the western Book Cliffs have reported a small number of channel-margin dikes that are large scale and that display a variety of shapes far different from those previously described in this report. Rare and poorly documented large-scale dikes have been reported that are shaped like crude teardrops that cut entire coal seams (fig. 13). These dikes narrow near their attachment point near the base of roof channels and thicken dramatically toward the floor. The narrow portion of these dikes has jagged and well-defined contacts. Sills and (or) dikes less than a few centimeters thick can emanate from this narrow part. Near the floor, the dikes appear extremely swollen and blotted and display smooth and fairly even contacts. 


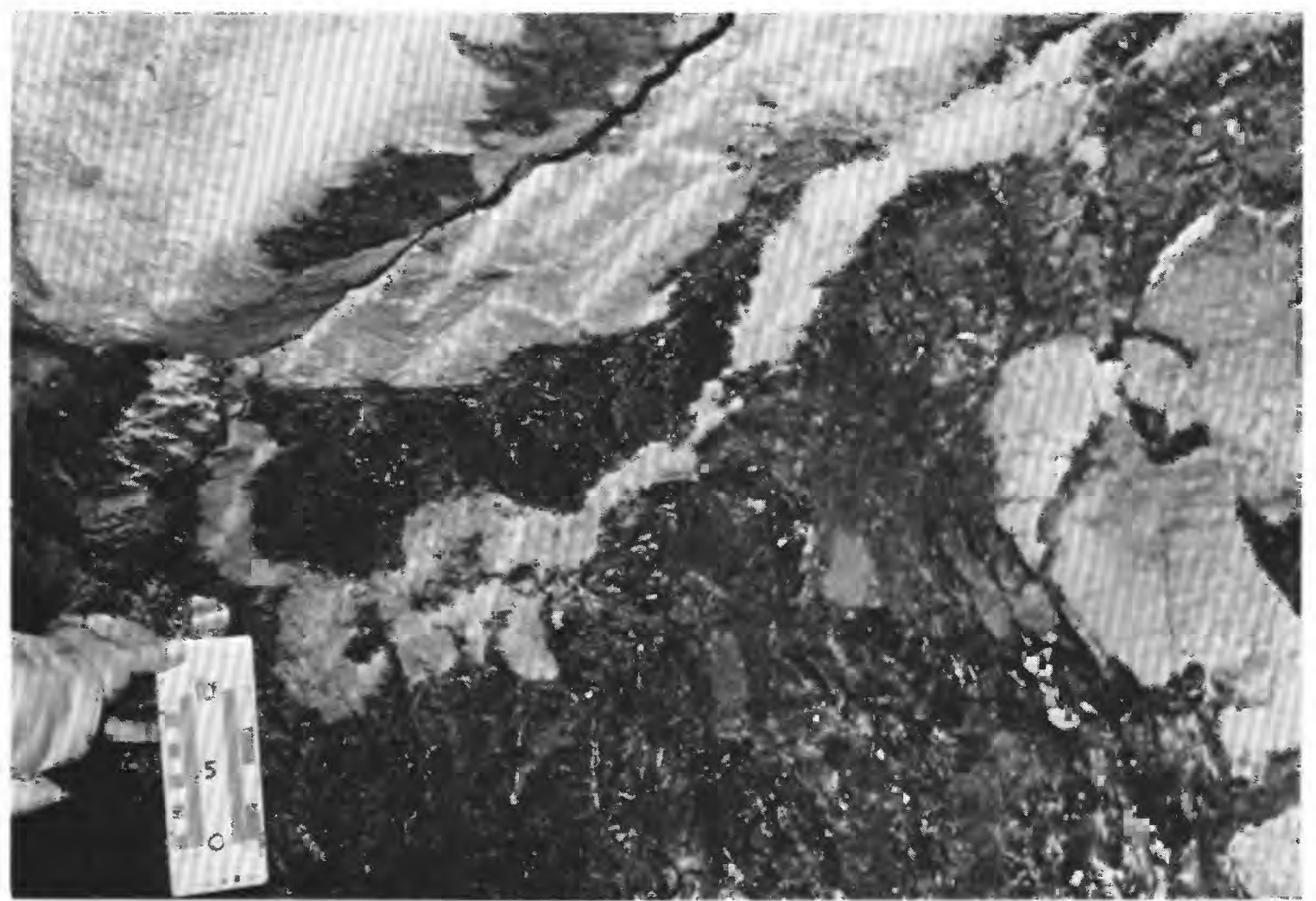

Figure 12. Channel-margin dike attached to a sandstone channel body in the roof of a coal seam. Centimeter scale card shown in lower left.

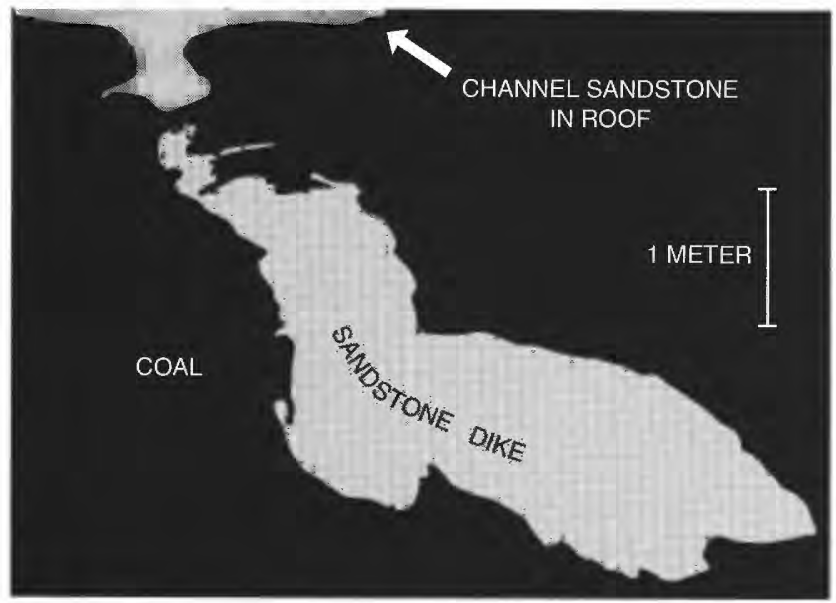

Figure 13. Sketch of large-scale channel-margin dike.

\section{INTERPRETATION}

Channel-margin dikes probably developed later than load-compaction dikes when sediment loading forced channel bodies into the top of peat beds forming tears that were infilled by channel material (fig. 2). The absence of well- developed crenulated character in high-angle dikes also suggests that channel-margin dikes formed later than loadcompaction dikes, after significant compaction of the peat. The widespread association of dikes and roof channels, particularly those that are physically attached to the margins of channels, and the similar composition of dikes and roof channel material demonstrate that channel bodies are the source of dike material. Vitrain bands that conform to the shape of channel bodies indicate that channel bodies were pressed into the upper surface of peat or lignite beds by the weight of the overlying sediments. Channel bodies, composed of grain-supported material, experienced little flattening out and compaction as they were imbedded into the surface of peat beds. The shallow and nonlinear penetration of dikes into the tops of coal seams and the attachment of dikes to channel bodies suggest that dikes formed from infilled tears in the peat. Once the tears were filled with channel material, continued sediment loading and compaction of the peat or lignite probably squeezed clastic material farther into the peat. The rare dikes that emanate from floor rolls probably formed in a similar manner. Their smaller size may be related to the effects of gravity. Kerns (1970) proposed a similar control for dikes associated with floor and roof rolls in the Pittsburgh coal seam of 
southwestern Pennsylvania. He suggested that tension cracks developed in areas adjacent to sand bodies where the peat was stretched and filled with sediments. Tectonism is not believed to have played a significant role in the formation of channel-margin dikes because of the apparent randomness of dike trends, the lack of consistent penetration by the dikes into the roof rock, and the relatively short lateral extent of the dikes.

The formation of large-scale dikes is unclear but probably is related to different physical states of the peat. The presence of jagged margins and small-scale sills and dikes emanating near the top of the dike may have resulted from injection of clastic material along zones of weakness in the younger and more fibrous peat after the infilling of tears. The smooth and bloated appearance of the dike in older peat near the bases of the beds may be the result of injection in peat that was more decomposed and gel-like. Had the entire peat bed been composed of fibrous vegetable matter, smaller and more typical channel-margin dikes probably would have formed. Another possibility is that large-scale dikes are actually load structures. Howard and Lohrengel (1969) described 12 pillow-shaped structures that range from 6 to $22 \mathrm{~m}$ in length in the northern part of the Wasatch Plateau and in approximately the same stratigraphic interval as large-scale channel dikes. They proposed that these features were large ball-and-pillow load structures detached from overlying strata and formed in a thick siltstone bed. If large-scale dikes formed in a similar manner, it is possible that the small-scale sills and dikes that emanate from the top of large-scale dikes resulted from differential lateral slippage along horizontal planes in the upper part of the peat bed.

\section{FRACTURE-FILL DIKES}

\section{DESCRIPTION}

Information on fracture-fill dikes is sketchy because of their small number and the limited opportunity the author has had to investigate them directly. Fracture-fill dikes have been reported in the northern and central parts of the Wasatch Plateau in at least three coal seams that span about $50 \mathrm{~m}$ of section that includes the Hiawatha seam. They are present as solitary features that measure from about $20 \mathrm{~cm}$ to more than a meter across near the floor and generally thin upward to a terminus in the upper to middle portions of coal seams, although a few dikes penetrate entire coal seams (fig. 14). Dikes are mostly composed of moderate to poorly indurated sandstone. In rare exposures, the terminus of these sandstone dikes is composed of siltstone or claystone. Although their lateral extent is unknown, the dikes have been reported to cut across multiple mine entries more than a hundred meters wide and disappear into mine walls. Dikes cut

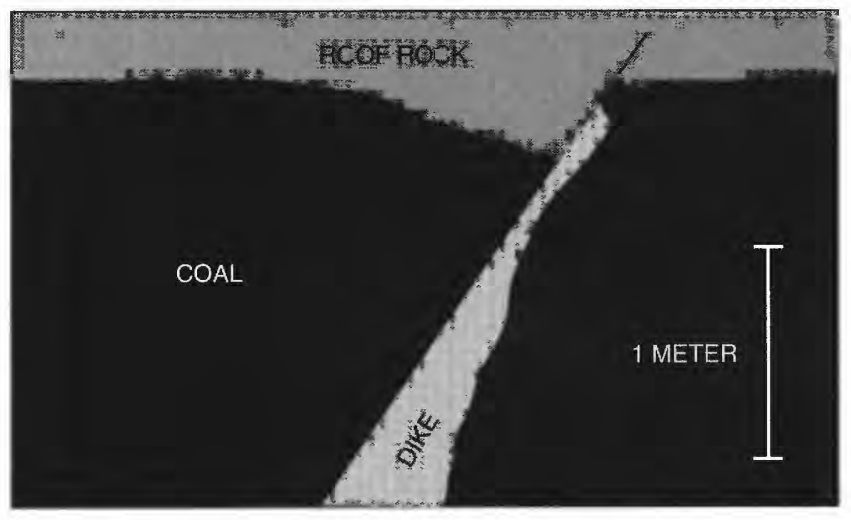

Figure 14. Sketch showing typical fracture-fill dike.

coal seams at high angles and are sharply bound along their uppermost contact by high-angle normal faults, although rare dikes have been reported that display no visible offset. Commonly, faults cut entire coal seams and display as much as $25 \mathrm{~cm}$ of offset that dies out near the roof line. The lower contact of dikes has a nonlinear and undulate character and displays no visible signs of offset (fig. 4).

\section{INTERPRETATION}

Fracture-fill dikes probably formed relatively late, after considerable coalification, as indicated by fault-bound contacts and the near absence of compaction-related features, including crenulation, microfaults, dike swelling, and coal fishtail structures. The upward thinning of fracturefill dikes and their tendency to pinch out near the top of coal seams show that dike material entered the base of coal seams. The presence of a single, sharp, fault-bound contact opposite an undulate contact suggests that offset occurred either after or during injection. If clastic material was injected into a fracture that was already faulted, both dike contacts would likely display a similar nonlinear character. At the time of injection, both contacts probably had a similar undulate character, but subsequent faulting probably healed those irregularities along the fault-bound contact. An apparent contradiction seems to exist, however, concerning the physical state of the peat at the time of faulting and injection. Characteristically, peat is a tough flexible material that would respond to the shear movement associated with faulting by stretching and tearing. The presence of smooth fault-bound dikes indicates that the peat was fairly well lithified when faulted; however, undulate dike contacts opposite faulted contacts suggest that the peat was flexible and easily deformed at the time of injection. One possible explanation involves the heterogeneity of vegetable matter within the peat. Peat beds are typically heterogenous bodies composed of layers of different types of vegetable matter having different physical characteristics including hardness. 
Injection into peat beds may have caused undulate contacts to develop as a result of different levels of yield associated with different layers within the peat. Fault-plane contacts may have experienced a healing of irregularities as faulting proceeded following injection.

\section{SIGNIFICANCE OF DIKES}

Clastic dikes in central Utah are believed to have at least three modes of origin, and each of the three major types of dikes probably formed at different times. Loadcompaction dikes probably formed very early, channelmargin dikes formed somewhat later but while organic material was still in the peat or lignite stage, and fracture-fill dikes formed relatively late after considerable coalification. Subsequent investigators of clastic dikes may find conflicting evidence of dike formation within a study area, only to find that dike formation involved more than one mechanism and that dike formation occurred during more than one time period.

Clastic dikes have created a range of extraordinary problems in underground coal mines that have resulted in increased production costs, mine closures, and injury of mine workers. Where dikes are present in numbers, recommended mining strategies include mining the upper part of coal seams where possible to avoid the thicker portions of dikes near the base of coal seams. Roof failure related to the cantilevering of roof rocks along zones of weakness at dike contacts can be reduced by driving mine entries at high angles to the central trend of dikes to reduce dike alignment with main entries.

Load-compaction dikes in central Utah are particularly interesting because of the many forms of dolomite present in the dike material, particularly the authigenic fraction. The presence of dolomite-rich dikes in peats that accumulated along a shoreline that was repeatedly transgressed suggests that seawater provided the magnesium necessary for precipitation of dolomite. Land (1985) proposed that seawater is the only common magnesium-rich fluid in the Earth's crust and must be the primary agent for the formation of dolomite. He went on to say that dolomite must form relatively early in the depositional history of sediments, when seawater or seawater-derived fluids can be actively pumped through sediments. Sibley (1991) wrote that, if one accepts Land's proposition, then the optimal situation for dolomitization is prolonged sea-level highstands or slow subsidence. The study area is an ideal laboratory for investigating dolomite formation because of the depositional setting, good exposures, and abundant mine access. Furthermore, the acidic nature of peat swamps and the early injection of dolomitic material are an interesting apparent contradiction that is worthy of investigation.

Clastic dikes are common in many North American basins where coal beds are associated with marine sequences and are uncommon to absent where coal accumulated in continental settings. Alluvial- plain coals, such as those of the Powder River Basin, Williston Basin, and Denver Basin, contain few, if any, dikes, according to the literature and the investigations conducted by the author. Dikes are common in many marginal-marine coals, including those in the Appalachian Basin, Illinois Basin, and Unita and Piceance Basins, and are particularly common in coals that accumulated directly on shoreface deposits. This association may be related to one or more factors including sustained water production through dewatering of marine shale, overpressuring of sand bodies beneath coal beds, and differential compaction of marine and marginal-marine sediments. Future investigations that compare and contrast coal-forming basins, both with and without clastic dikes and that also include non-coal-bearing marine sequences intruded by dikes may lead to a more comprehensive model of dike formation.

\section{REFERENCES CITED}

Athy, F., 1930, Density, porosity and compaction of sedimentary rocks: American Association of Petroleum Geologists, v. 14, no. 1, p. 1-24.

Armstrong, R.L., 1968, Sevier orogenic belt in Nevada and Utah: Geologic Society of American Bulletin, v. 79, no. 4, p. $429-458$.

Balsley, J.K., 1980, Cretaceous wave-dominated delta system, Book Cliffs, east central Utah: AMOCO Production Company Guidebook, 162 p.

Bennett, P.C., Siegel, D.I., Hill, M.B., and Glaser, P.H., 1991, Fate of silicate minerals in a peat bog: Geology, v. 19, p. 328-331.

Boreck, D.L., 1986, Thick and closely spaced coal deposits in a tristate region, western U.S., and the geologic factors affecting their development: Available from D.L. Boreck, Denver Research Center, U.S. Bureau of Mines, $105 \mathrm{p}$.

Bunnell, M.D., and Taylor, T.W., 1987, Roof geology and coal seam characteristics of the No. 3 Mine, Hardscrabble Canyon, Carbon County, Utah: Utah Geology and Mineral Survey Special Studies 69, 39 p.

Cady, G.H., 1942, Strip mining and agriculture in Illinois: Unpublished manuscript available from Illinois State Geological Survey, file MS C-2, p. 131-133.

Chase, F.E., and Ulery, J.P., 1987, Clay veins-Their occurrence, characteristics, and support: U.S. Bureau of Mines Report of Investigations 9060, 19 p.

Close, J.C., 1991, Natural fractures in bituminous coal gas reservoirs: Gas Research Institute Topical Report GRI-91/0337, p. 11-15.

1992, Western Cretaceous coal seam project; Quarterly Review of Methane from Coal Seams Technology, v. 10, no. 1, p. 11-15.

Crane, W.R., 1898, Horsebacks in Kansas coal measures: The Kansas University Quarterly, v. 4, no. 3, p. 145-151, and Geologic Survey of Kansas Special Report, v. 3, p. 195-213.

Damberger, H.H., 1973, Physical properties of the Illinois Herrin (No. 6) Coal before burial as inferred from earthquake-induced 
disturbances: International Congress of Carboniferous Stratigraphy and Geology, 70th, Proceedings, v. 7, no. 2, p. 341-350.

Davis, F.D., and Doelling, H.H., 1977, Coal drilling at Trail Mountain, North Horn Mountain, and Johns Peak Areas, Wasatch Plateau, Utah: Utah Geological and Mineral Survey Bulletin $112,90 \mathrm{p}$.

Doelling, H.H., 1979, Sandstone spar in the Trail Mountain coal mine, Emery County, Utah: Utah Geology, v. 6, no. 2, p. $57-68$.

Dunrud, R.C., 1976, Some engineering geologic factors controlling coal mine subsidence in Utah and Colorado: U.S. Geological Survey Professional Paper 969, 39 p.

Ellenberger, J.L., 1979, Slickenside occurrence in coal mine roof of the Valley Camp No. 3 near Wheeling, West Virginia: U.S. Bureau of Mines Report of Investigations 8365, 17 .

Elliott, R.E., 1965, A classification of subaqueous sedimentary structures based on rheological and kinematical parameters: Sedimentology, v. 5, p.193-209.

Flores, M.F., Blanchard, L.F., Sanchez, J.D., Marley, W.E., and Muldoon W.J., 1984, Paleogeographic controls of coal accumulation, Cretaceous Blackhawk Formation and Star Point Sandstone, Wasatch Plateau, Utah: Geological Society of America Bulletin, v. 95, p. 540-550.

Flores, M.F., Marley, W.E., Sanchez, D.K., Blanchard, L.F., and Muldoon, W.J., 1982, Coal correlations and depositional environments of Cretaceous Blackhawk Formation and Star Point Sandstone, Wasatch Plateau, Utah: Utah Geological and Mineral Survey Bulletin 118, p. 70-75.

Foster, J.L., and Karlstrom, 1967, Ground breakage and associated effects in the Cook Inlet area, Alaska, resulting from the March 27, 1964, earthquake: U.S. Geological Survey Professional Paper 543, 28 p.

Gresley, W.S., 1897, Clay-veins vertically intersecting coal measures: Geologic Society of America Bulletin, v. 9, p. 35-58.

Hardie, J.K., 1992, Clastic dikes in Campanian coals; controlled by tectonics in western Colorado and by sedimentary architecture in central Utah: Society of Economic Paleontologists and Mineralogists, International Fluvial Sedimentology Conference, 3rd, Abstracts Volume, p. 29.

-1991, Dolomite-rich clastic dikes and sills intruding Campanian coals of central Utah: Geological Society of America Abstracts with Programs, v. 23, no. 5, p. A144.

Hardie, J.K. and Bostick, N.H., 1993, Siliciclastic dikes in and near the Cameo coal mine, western Colorado, and dolomite dikes in the Trail Mountain mine, central Utah: Annual International Pittsburgh Coal Conference, 10th, Proceedings, p. 1068-1073.

Hardie, J.K. and Fleck, K.S., 1991, Clastic dikes and sills in Campanian coals, Wasatch Plateau coal field, Utah: Geological Society of America Abstracts with Programs, v. 23, no. 4, p. 30.

Hesse, R., and Reading, H.G., 1978, Subaqueous clastic fissure eruptions and other examples of sedimentary transposition in the lacustrine Horton Bluff Formation (Mississippian), Nova Scotia, Canada: International Association of Sedimentologists Special Publication 2, p. 241-257.

Hill, J.L., and Bauer, E.R., 1984, An investigation of the causes of cutter roof failure in a central Pennsylvania coal mine: U.S Rock Mechanics Symposium, 25th, Proceedings, p. 603-613.

Hoover, H.C., and Hoover, L.H., translators, 1950, De re metallica of Georgius Agricola (translation of first Latin edition, 1556): New York, Dover.

Howard, J.D., 1969, Depositional control of Upper Cretaceous coal units: The Mountain Geologist, v. 6, no. 3, p. 143-146.
Howard, J.D., and Lohrengel, C.F., II, 1969, Large non-tectonic deformational structures from Upper Cretaceous rocks of Utah: Journal of Sedimentary Petrology, v. 39, no. 3, p. 1032-1039.

Jepsen, K.O., 1987, Petrographic study of the Star Point Sandstone and Blackhawk Formation (Upper Cretaceous), East Mountain, Emery County, Utah: Fort Hays, Kansas, Fort Hays State University, M.S. thesis, $77 \mathrm{p}$.

Johnson, J.L., 1979, Stratigraphy of the coal-bearing Blackhawk Formation of North Horn Mountain, Wasatch Plateau, Utah: Utah Geology, v. 5, no. 1, p.57-77.

Johnson, T., 1982, Occurrence of sandstone spar in the Trail Mountain coal mine Emery County, Utah: Available from the Utah State Geologic Survey, 39 p.

Kendall, P.F., 1919, On "wash-outs" in coal-seams and the effects of contemporary earthquakes: Geological Society of London Proceedings, no. 1031, session 1918-19, p. 28-31.

Kerns, E.G., 1970, Clay dikes in the Pittsburgh Coal of southwestern Greene County, Pennsylvania: Morgantown, West Virginia University, M.S. thesis, $47 \mathrm{p}$.

Land, L.S., 1985, The origin of massive dolomite: Journal of Geological Education, v. 33, p. 112-125.

Lindberg, J.W., Mercier, J.M., and Bunnell, M.D., 1983, Clastic dikes and their occurrence in coal deposits of central Utah, Geologic Society of America Abstracts with Programs, v. 15, no. 4 , p. 289.

Moebs, N.N., and Stateham, R.M., 1986, Coal mine roof instability: U.S. Bureau of Mines Information Circular 9076, 15 p.

Newsom, J.F., 1903, Clastic dikes: Geologic Society of America Bulletin, v. 14, p. 227-268.

Oldham, F.R., and Mallet, R., 1872, Notice of some of the secondary effects of the earthquake of 10th January, 1869, in Cachar: Geologic Society of London Quarterly Journal, v. 28, p. 255-270.

Raistrick, A., and Marshall, C.E., 1939 [1948], Wash-outs and associated phenomena, in The nature and origin of coal and coal seams: London, English University Press, p. 79-101.

Saucier, R.T., 1977, Evidence for episodic sand-blow activity during the 1811-1812 New Madrid (Missouri) earthquake series: Geology, v. 17, p. 103-106.

Savage, T.E., 1910, Clay seams or so-called horsebacks near Springfield, Illinois: Economic Geology, v. 5, no. 2, p. 178-187.

Shea-Albin, V.R., in press, Geological features that contribute to ground control problems in underground coal mines: Denver Research Center, U.S. Bureau of Mines Information Circular, $130 \mathrm{p}$.

Shirley, Jack, 1955, The disturbed strata on the Fox Earth Coal and its equivalents in the East Pennine Coal Field: Geologic Society of London Quarterly Journal, v. 111, p. 265-282.

Sibley, D.F., 1991, Secular changes in the amount and texture of dolomite: Geology, v. 19, p. 151-154.

Teichmuller, M., and Teichmuller, R., 1968, Geological aspects of coal metamorphism, in Murchison, C., and Westoll, T.S., eds., Coal and coal-bearing strata: Edinburgh, Oliver and Boyd, p. 233-267.

Young, R.G., 1965, Sedimentary facies and intertonguing in the Upper Cretaceous of the Book Cliffs, Utah-Colorado: Geology Society of America Bulletin, v. 66, p. 177-202.

Williamson, I.A., 1967, Washouts and splits in coal seams, in Coal mining geology: London, Oxford University Press, p. 193-201.

Wilson, W.B., 1916, The origin of clay slips: Economic Geology, v. 9, p. 381-389. 


\section{SELECTED SERIES OF U.S. GEOLOGICAL SURVEY PUBLICATIONS}

\section{Periodicals}

Earthquakes \& Volcanoes (issued bimonthly).

Preliminary Determination of Epicenters (issued monthly).

\section{Technical Books and Reports}

Professional Papers are mainly comprehensive scientific reports of wide and lasting interest and importance to professional scientists and engineers. Included are reports on the results of resource studies and of topographic, hydrologic, and geologic investigations. They also include collections of related papers addressing different aspects of a single scientific topic.

Bulletins contain significant data and interpretations that are of lasting scientific interest but are generally more limited in scope or geographic coverage than Professional Papers. They include the results of resource studies and of geologic and topographic investigations; as well as collections of short papers related to a specific topic.

Water-Supply Papers are comprehensive reports that present significant interpretive results of hydrologic investigations of wide interest to professional geologists, hydrologists, and engineers. The series covers investigations in all phases of hydrology, including hydrology, availability of water, quality of water, and use of water.

Circulars present administrative information or important scientific information of wide popular interest in a format designed for distribution at no cost to the public. Information is usually of short-term interest.

Water-Resources Investigations Reports are papers of an interpretive nature made available to the public outside the formal USGS publications series. Copies are reproduced on request unlike formal USGS publications, and they are also available for public inspection at depositories indicated in USGS catalogs.

Open-File Reports include unpublished manuscript reports, maps, and other material that are made available for public consultation at depositories. They are a nonpermanent form of publication that may be cited in other publications as sources of information.

\section{Maps}

Geologic Quadrangle Maps are multicolor geologic maps on topographic bases in $71 / 2$ - or 15 -minute quadrangle formats (scales mainly $1: 24,000$ or $1: 62,500$ ) showing bedrock, surficial, or engineering geology. Maps generally include brief texts; some maps include structure and columnar sections only.

Geophysical Investigations Maps are on topographic or planimetric bases at various scales, they show results of surveys using geophysical techniques, such as gravity, magnetic, seismic, or radioactivity, which reflect subsurface structures that are of economic or geologic significance. Many maps include correlations with the geology.

Miscellaneous Investigations Series Maps are on planimetric or topographic bases of regular and irregular areas at various scales; they present a wide variety of format and subject matter. The series also includes 7 1/2-minute quadrangle photogeologic maps on planimetric bases which show geology as interpreted from aerial photographs. The series also includes maps of Mars and the Moon.
Coal Investigations Maps are geologic maps on topographic or planimetric bases at various scales showing bedrock or surficial geology, stratigraphy, and structural relations in certain coal-resource areas.

Oil and Gas Investigations Charts show stratigraphic information for certain oil and gas fields and other areas having petroleum potential.

Miscellaneous Field Studies Maps are multicolor or black-andwhite maps on topographic or planimetric bases on quadrangle or irregular areas at various scales. Pre-1971 maps show bedrock geology in relation to specific mining or mineral-deposit problems; post-1971 maps are primarily black-and-white maps on various subjects such as environmental studies or wilderness mineral investigations.

Hydrologic Investigations Atlases are multicolored or black-andwhite maps on topographic or planimetric bases presenting a wide range of geohydrologic data of both regular and irregular areas; the principal scale is 1:24,000, and regional studies are at 1:250,000 scale or smaller.

\section{Catalogs}

Permanent catalogs, as well as some others, giving comprehensive listings of U.S. Geological Survey publications are available under the conditions indicated below from USGS Map Distribution, Box 25286, Building 810, Denver Federal Center, Denver, CO 80225. (See latest Price and Availability List.)

"Publications of the Geological Survey, 1879-1961" may be purchased by mail and over the counter in paperback book form and as a set microfiche.

"Publications of the Geological Survey, 1962-1970" may be purchased by mail and over the counter in paperback book form and as a set of microfiche.

"Publications of the U.S. Geological Survey, 1971-1981" may be purchased by mail and over the counter in paperback book form (two volumes, publications listing and index) and as a set of microfiche.

Supplements for 1982, 1983, 1984, 1985, 1986, and for subsequent years since the last permanent catalog may be purchased by mail and over the counter in paperback book form.

State catalogs, "List of U.S. Geological Survey Geologic and Water-Supply Reports and Maps For (State)," may be purchased by mail and over the counter in paperback booklet form only.

"Price and Availability List of U.S. Geological Survey Publications," issued annually, is available free of charge in paperback booklet form only.

Selected copies of a monthly catalog "New Publications of the U.S. Geological Survey" is available free of charge by mail or may be obtained over the counter in paperback booklet form only. Those wishing a free subscription to the monthly catalog "New Publications of the U.S. Geological Survey" should write to the U.S. Geological Survey, 582 National Center, Reston, VA 22092.

Note.-Prices of Government publications listed in older catalogs, announcements, and publications may be incorrect. Therefore, the prices charged may differ from the prices in catalogs, announcements, and publications. 
